DIW BERLIN

Discussion

Papers
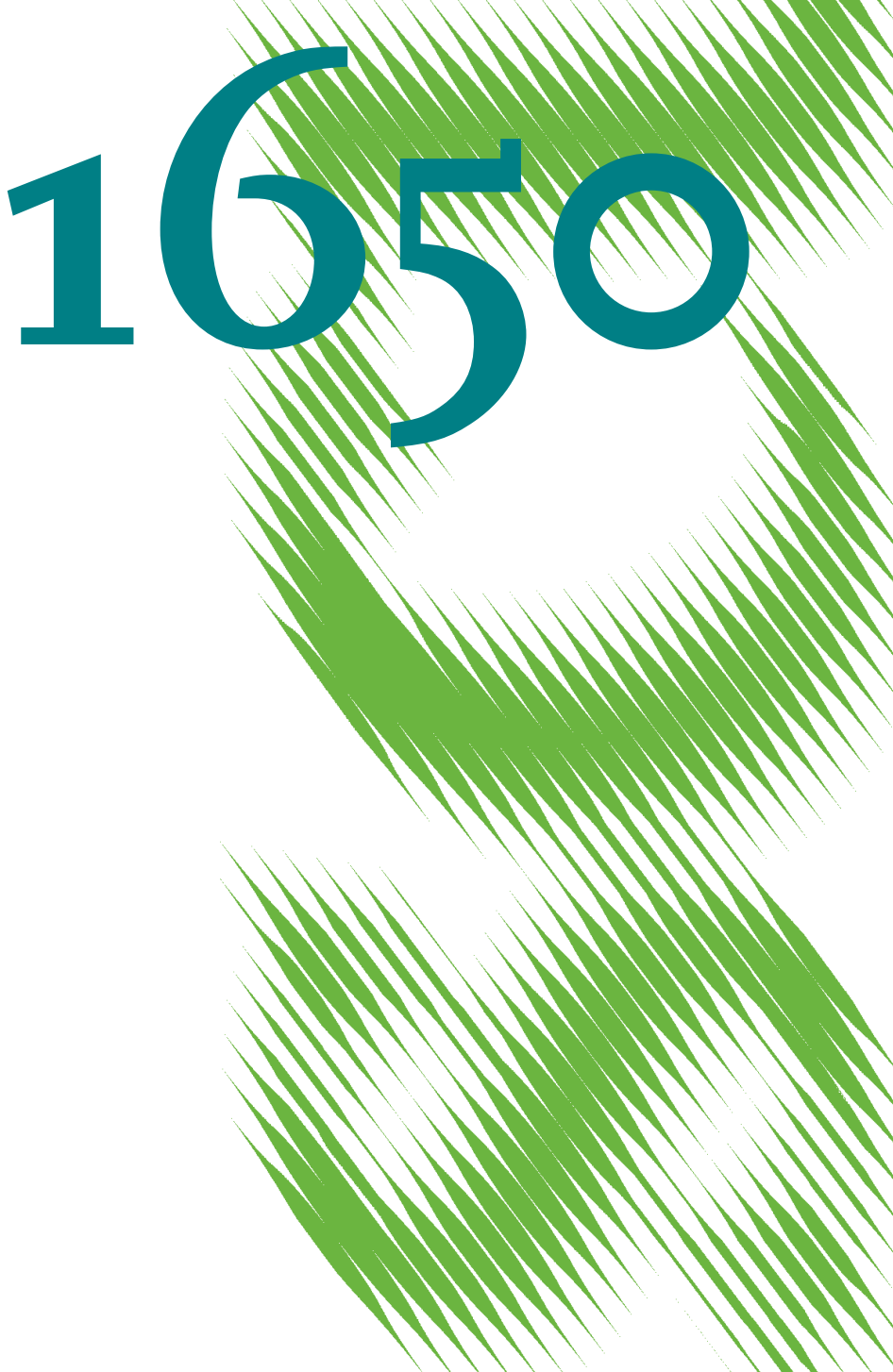

Don't Stop Me Now: The Impact of Credit Market Fragmentation on Firms' Financing Constraints 
Opinions expressed in this paper are those of the author(s) and do not necessarily reflect views of the institute.

IMPRESSUM

(C) DIW Berlin, 2017

DIW Berlin

German Institute for Economic Research

Mohrenstr. 58

10117 Berlin

Tel. +49 (30) $89789-0$

Fax +49 (30) $89789-200$

http://www.diw.de

ISSN electronic edition 1619-4535

Papers can be downloaded free of charge from the DIW Berlin website:

http://www.diw.de/discussionpapers

Discussion Papers of DIW Berlin are indexed in RePEc and SSRN:

http://ideas.repec.org/s/diw/diwwpp.html

http://www.ssrn.com/link/DIW-Berlin-German-Inst-Econ-Res.html 


\title{
Don't Stop Me Now: \\ The Impact of Credit Market Fragmentation on Firms' \\ Financing Constraints*
}

\author{
Franziska Bremus \\ German Institute for Economic Research (DIW Berlin)** \\ Katja Neugebauer \\ Systemic Risk Centre, London School of Economics and Political Science (LSE) ${ }^{\S}$
}

March 9, 2017

\begin{abstract}
This paper investigates how the withdrawal of banks from their cross-border business impacted the borrowing costs of European firms since the crisis. We combine aggregate information on total and cross-border credit with firm-level survey data for the period 2010 - 2014. We find that the decline in cross-border lending led to a deterioration in the borrowing conditions of small firms. In countries with more pronounced reductions in cross-border credit inflows, the likelihood of a rise in firms' external financing costs has increased. This result is mainly driven by the interbank channel, which plays a crucial role in transmitting shocks to the real sector across borders.
\end{abstract}

JEL-Classifications: F34, F36, G15, G21.

Keywords: International banking, firm finance, credit constraints

\footnotetext{
*The project benefited from financial support from the Volkswagen Foundation under the project "Europe's Global Linkages and the Impact of the Financial Crisis: Policies for Sustainable Trade, Capital Flows, and Migration." The support of the Economic and Social Research Council (ESRC) in funding the Systemic Risk Centre is gratefully acknowledged [grant number ES/K002309/1]. We thank the ECB for providing access to the SAFE micro-level data, as well as Katarzyna Bankowska, Nicola Benatti, and Annalisa Ferrando for valuable advice on the data. We thank Carlo Altomonte, John Bonin, Claudia Lambert, Mathias Klein, Philipp Schaz, Marcel Smolka, Lena Tonzer, and conference and seminar participants at DIW Berlin, the Systemic Risk Centre (LSE), the 2016 ASSA Meetings, the German Economic Association, the IMT Lucca, University College London, and the XXIV International Rome Conference on Money, Banking and Finance for helpful comments and discussions. All errors and inconsistencies are solely in our own responsibility.

${ }^{* *}$ German Institute for Economic Research (DIW Berlin), Mohrenstr. 58, 10117 Berlin, Germany. Email: fbremus@diw.de. Phone: +49 (0)30 89789590.

\$Systemic Risk Centre, LSE, Houghton Street, London WC2A 2AE, UK. Email: K.Neugebauer@lse.ac.uk. Phone: +44 (0)20 78494961.
} 


\section{Introduction}

This study aims at contributing to a better understanding of the impact of changes in international credit market integration on the real economy. Previous literature shows that financial integration alleviates the financing constraints of firms (e.g. Harris et al. 1994, Gallego and Loayza 2001), with some studies finding that small firms can especially benefit from credit market liberalization (Gelos and Werner 2002, Laeven 2002). Given that the global financial crisis led to a considerable retrenchment in international capital flows, our goal is to investigate how the reduction in cross-border bank lending affected the access to finance for small and medium-sized enterprises (SMEs) in the euro area.

We contribute to the literature by analyzing the implications of credit market fragmentation for SMEs within the euro area, while other studies focus on developing or emerging economies. In contrast to previous studies, the question we ask here is whether the drop in foreign lending since the crisis - both in the form of direct cross-border credit and in the form of lending via foreign affiliates - has increased borrowing costs for firms. Indeed, our regression results indicate that firms in countries that experienced sharper reductions in cross-border credit inflows were more likely to see their credit costs rise. When comparing the importance of credit inflows to banks and to non-banks for this effect, we find that it is mainly the fragmentation of the interbank credit market that drives the negative link between cross-border credit and credit costs of SMEs in the euro area.

Several studies show that credit markets have become more fragmented since the crisis (Cetorelli and Goldberg 2011, Bruno and Shin 2013, Milesi-Ferretti and Tille 2011, Lane 2013, 2014a,b, Bremus and Fratzscher 2015), and that the decline in cross-border bank lending is particularly pronounced and persistent in the euro area. According to Wehinger (2013), SMEs are particularly affected by financial fragmentation. ${ }^{1}$ Overall, in the euro area, new bank credit to small firms declined by 35 percent between 2008 and 2013, with SMEs reporting deteriorating credit availability in many euro area countries (Figure 1). Regarding SMEs' costs of funding, although average loan rates for firms have decreased since 2012, the spreads between loan rates for small and large loans have increased significantly (Figures 2), especially in those countries hit hardest by the crisis.

Owing to the fact that firms in the euro area are highly dependent on bank financing, tight credit market conditions can importantly limit their access to external finance. As

\footnotetext{
${ }^{1}$ Reasons for the borrowing limits faced by small firms include their opaqueness and, hence, the larger information asymmetries between banks and small firms compared to larger and listed firms for which hard information is readily available.
} 
SMEs make up for more than 98 percent of non-financial firms in the EU, about 60 percent of gross value added, and nearly 70 percent of employment, their credit conditions play an important role for investment, innovation, and growth in the euro area.

Combining firm-level with macroeconomic data, we run probit regressions to test different channels through which credit market fragmentation affects the financing constraints of SMEs. External financing costs are measured using micro-level data from the Survey on Access to Finance of Enterprises in the Euro Area (SAFE). The SAFE data contain information on borrowing conditions and business characteristics of European SMEs. Aggregate credit data come from the International Banking Statistics and from the Statistics on Credit to the Private Sector provided by the Bank for International Settlements.

The data reveal that access to finance was, indeed, among the most pressing problems for SMEs in the euro area in the aftermath of the crisis (Figure 3). However, there are pronounced differences across countries. Not surprisingly, access to finance is particularly problematic in the periphery countries. In contrast, only about six percent of German firms listed access to finance as their most pressing problem at the end of 2013. These differences across countries potentially point to a strong fragmentation of credit markets in the euro area, with capital not necessarily flowing to where it can be employed most fruitfully. Our regression analysis examines this issue in more detail by looking at the impact of changes in cross-border credit flows on firms' financing costs.

Credit market segmentation can affect firms' access to finance through different channels. First, a decline in credit inflows from abroad can increase financing costs because of reduced direct cross-border lending to firms (at arms-length or through foreign affiliates). As shown by firm-level survey-data from the EFIGE project for seven European countries, ${ }^{2}$ on average, about eight percent of SMEs used foreign bank credit in 2008/09. However, there is a considerable degree of heterogeneity across countries. Whereas nearly 15 percent of French SMEs used services by foreign banks, less than five percent of German SMEs did so.

Second - even if individual firms do not have a direct relationship with foreign banks - a decrease in foreign credit inflows has indirect effects on the firm's financing conditions through its impact on the domestic credit market. On the one hand, contestability and, hence, competitive pressures in the domestic banking sector decrease due to fragmentation - with potentially adverse effects on the retail credit market. Consequently, banks may charge higher lending rates to their clients (Bremus 2015, de Blas and Russ 2013). On the

\footnotetext{
${ }^{2}$ Austria, France, Germany, Hungary, Italy, Spain, United Kingdom. For more details, see Altomonte and Aquilante (2012).
} 
other hand, credit market fragmentation can reduce domestic lending if the (wholesale) funding conditions of domestic banks deteriorate (Feyen et al. 2014, Brei 2007) as crossborder interbank credit becomes scarce. For the case of Turkey, Baskaya et al. (2017) find a positive link between the credit supply of domestic banks that have a higher share of wholesale liabilities and capital inflows. Hence, wholesale and interbank funding seems to be an important transmission channel of global credit cycles.

Our estimation results indicate, first, that SMEs in countries experiencing stronger reductions in cross-border bank lending are more likely to face increasing loan rates. This relationship is meaningful both statistically and economically. Second, the negative

link between cross-border credit growth and financing costs of SMEs seems to be driven primarily by the interbank lending channel. The stronger the reduction in cross-border credit to the banking system, the more likely firms are to see their loan rates rise. Yet, the impact of direct cross-border lending from banks to firms is statistically insignificant in our setup.

The remainder of the paper is structured as follows. In the next section, we discuss how our study is related to previous literature. Section 3 gives a detailed overview of the data employed and the empirical methodology used. Section 4 presents the regression results, and section 5 concludes.

\section{Related Literature}

Our analysis is related to two main strands of literature. First, we contribute to the literature on external financing constraints of small firms. Several studies use survey information on the perceived and actual financing obstacles reported by firms, e.g. from the World Business Environment Survey (Beck et al. 2006, Beck et al. 2008, Coluzzi et al. 2012), from the Business Environment and Enterprise Performance Survey (BEEPS), or, more recently, from the SAFE.

Using SAFE data for the 2009-2011 period, Ferrando and Mulier (2015) present evidence that less productive, more leveraged, and younger SMEs are more likely to face external financing constraints. The authors argue that the global financial crisis is a good starting point to study external financing constraints, as SMEs in the euro area were likely to experience increased financing obstacles during the post-crisis period. In addition, the subsequent debt crisis in the euro area and the structural changes, especially in the crisis-hit periphery countries, impaired the availability of external financing, especially for the more opaque SMEs. Artola and Genre (2011) use panel data from SAFE 
for the 2009-2010 period in order to study which firm characteristics affected the access to finance of SMEs during the crisis. Their estimation results reveal that, in particular, young and small firms have experienced credit constraints. In a cross-sectional analysis of 2009, Ferrando and Griesshaber (2011) find that age and ownership are important drivers of perceived financing constraints: older firms and firms owned by shareholders or other firms are less financing constrained. Holton et al. (2014) explore the impact of the crisis on credit supply and demand using SAFE data for 2009 to 2011 for the EU. They show that banks tightened lending standards, but that credit demand by SMEs was also reduced.

In a study relying on the BEEPS data for Eastern Europe and the Caucasus, Beck et al. (2014) present evidence that banks' lending techniques matter for credit constraints of SMEs. They show that relationship lending reduces financing constraints in cyclical downturns, but not in booms. Using confidential micro-data on Portuguese banks and firms, Iyer et al. (2014) look at the effect that the drying up of the interbank market had on loan availability for firms. They find that smaller firms especially had problems in accessing finance due to reductions in interbank lending. Furthermore, small firms were not able to substitute banks loans with other sources of finance.

Apart from survey data, a large set of studies exploit firm balance sheet information in order to measure financing constraints by the sensitivity of investment to cash-flow. The idea is that financially constrained firms are more cash-flow sensitive than unconstrained firms. That is, constrained firms must rely more on internal funding (Fazzari and Petersen 1993). Yet, cash-flow sensitivity as a measure of financing constraints is criticized (Kaplan and Zingales 1997, Kaplan and Zingales 2000). Following Almeida et al. (2004), several papers alternatively measure firms' financing obstacles by the cash flow sensitivity of cash - a measure more focused on the financial situation of the firm than the cash-flow sensitivity of investment. Based on the cash-flow sensitivity of cash, Baum et al. (2011) find that the financial architecture is important for reducing the financing constraints of small firms: bank-based systems tend to provide better access to finance for SMEs than market-based systems in normal times. However, the authors point out that the results may differ in crisis times. We contribute to this literature by addressing the question of how changes in the degree of credit market integration affect the credit costs of SMEs in the euro area.

A second - but smaller - strand of the literature is devoted to the link between crossborder banking and the external financing constraints of small firms. While, among others, Berger et al. (2001) and Mian (2006) show that foreign banks avoid lending to small and opaque firms in developing countries, Clarke et al. (2001) and Clarke et al. (2005) find 
that foreign banks lend to small firms in developing and emerging economies at least as much as domestic banks do. Other studies point in the same direction: After financial liberalization, the cash-flow sensitivity of investment was reduced in Chile (Gallego and Loayza 2001), Indonesia (Harris et al. 1994), and for small firms in Mexico (Gelos and Werner 2002). Laeven (2002) studies the impact of financial liberalization on firms' access to finance using a panel of 13 developing countries over the 1988-1998 period. After liberalization, small listed firms' investment become less sensitive to changes in cash-flow, i.e. firms become less financially constrained. However, large firms become more constrained after liberalization - possibly due to preferential treatment before liberalization. In a similar vein, Forbes (2007) presents evidence that smaller listed companies are more hurt by the introduction of capital controls than larger ones.

Beck et al. (2011) explore bank-level survey evidence from 2006 to analyze to what extent and under which conditions foreign and domestic banks lend to SMEs. Their sample includes 11 large banks operating in advanced economies and 80 large banks operating in developing countries. Against the conventional view that small, domestic banks are more likely to give credit to SMEs, the authors present evidence that foreign banks lend as much to SMEs as do domestic banks. Yet, foreign banks use different lending techniques and organizational structures.

Giannetti and Ongena (2009) study the effects of foreign bank entry on young, small Eastern European firms, both listed and unlisted. Using a linked micro-macro dataset, they find that foreign bank presence fosters firms' use of loans and reduces their cost of debt. However, large firms benefit more from a foreign bank entry than do small firms. Based on survey data for a set of Eastern European countries in 2005 and 2008, Popov and Udell (2012) present evidence that, during the crisis, SMEs' financing constraints were affected by the deterioration of their banks' financial health. In addition, they show that the balance sheet weaknesses of foreign parent banks translated into financing obstacles for SMEs.

\section{Data and Empirical Methodology}

In order to analyze the effects of the reduction in international bank lending on the financing conditions of SMEs since the crisis, we use a linked micro-macro dataset for 11 euro area countries over the 2010-2014 period. Detailed information on the data used is in the Data Appendix. 


\subsection{Micro-Level Data}

Firm-level information on financial conditions in the euro area is provided by SAFE, from the ECB. The survey covers a wide array of qualitative information on the access to finance for non-financial firms in Europe; predominantly in the euro area. It is representative at the euro-area level, as well as for the four largest countries Germany, France, Italy, and Spain.

SAFE was started in 2009 and is conducted semi-annually. While 'wave 1' (W1) of each survey year covers the second and third quarter of that year, 'wave 2' (W2) captures the fourth quarter of the year and the first quarter of the following year. Therefore, our sample covers the period 2010Q4-2014Q1 (i.e. 2010W2-2013W2). We only include information starting with 2010W2 because previous waves covered considerably fewer firms and relatively more firms from the largest four euro area countries. Each of the survey rounds included here covers more than 5,000 firms. During the period under study, the survey was conducted in so-called ECB waves and European Commission waves. The ECB waves cover a limited number of euro area countries, whereas the Commission waves cover all euro area countries and some surrounding countries. ${ }^{3}$ Given that we want to make use of the time dimension in the data, we keep only those countries that are included in all waves. These are Austria, Belgium, Finland, France, Germany, Greece, Ireland, Italy, the Netherlands, Portugal, and Spain. Table 1 provides an overview of the number of firms included in our regression sample by country and wave.

To achieve representativeness, the SAFE sample is stratified by country, firm size class, and economic activity. The sample covers the following size classes: micro (1-9 employees), small (10-49 employees), and medium-sized (50-249 employees) enterprises. For reasons of comparison, a sample of large enterprises (more than 250 employees) is also included. In terms of economic activity, stratification is done at the one-digit level of NACE rev.1.1. Economic activities include the four broad sectoral categories of Industry, Construction, Trade, and Services. ${ }^{4}$

Table 2 provides a detailed overview of the distribution of firms according to different characteristics. With respect to firm size, three quarters of firms in the sample employ

\footnotetext{
${ }^{3}$ For a detailed overview over the countries covered in the different waves, see ECB (2014).

${ }^{4}$ Industry includes: mining and quarrying; manufacturing; electricity, gas, steam and air conditioning supply; water supply, sewerage, waste management and remediation activities; Trade: wholesale and retail trade; repair of motor vehicles, motorcycles and personal household goods; and Services: enterprises in transport and storage; accommodation and food service activities; information and communication; real estate activities; professional, scientific and technical activities; administrative and support service activities; arts, entertainment and recreation; other service activities.
} 
less than 50 workers, and about 50 percent of firms have an annual turnover of less than two million euros. The most important sectors are Services (37 percent of firms) and Trade (28 percent). Interestingly, although the majority of firms is very small, nearly 80 percent of the firms are at least 10 years old. Regarding ownership, more than 80 percent of firms belong to families or an individual person.

Firms' credit costs. Our main focus is on changes in firms' cost of external financing. The SAFE data reveal that European SMEs frequently use bank loans as well as overdrafts and credit lines as a means of external funding. In our sample, an average of about 40 percent of SMEs in the euro area rely on these bank-intermediated funding sources. Again, reliance on different financing instruments varies significantly across countries. Yet, bank credit and overdrafts rank among the most important external funding sources.

SAFE question Q10, which asks about the firm's change in loan rates, is used in order to measure changes in firms' incurred financing costs, applying a dummy variable that takes on the value of 1 if a firm experienced an increase in its rates on bank loans, overdrafts, or credit lines over the previous six months, and zero otherwise. This measure covers all firms that have applied for or renewed bank loans over the previous six months. Thus, SAFE allows us to concentrate on changes in the financing conditions for new loans. In addition, we construct a categorical variable that equals 1 if a firm experienced a reduction in its loan rates, 2 if the loan rate remained unchanged, and 3 if it went up.

Table 3 provides information on firms' financing conditions by country and across time. It reveals that, across countries, SMEs are affected quite differently. While, on average, 20 percent of German SMEs in our sample report loan rate increases during the period 2010W2 - 2013W2, nearly 80 percent of Spanish firms have done so. Overall, small firms in the GIIPS-countries have suffered much more from loan rate increases than SMEs in the remaining euro area countries. Regarding the evolution of credit conditions over time, loan rates increased most broadly in 2011. Since then, fewer firms have experienced increasing loan rates. Still, about 30 percent of firms in our sample report an increase in credit costs during the 2013Q4 - 2014Q1 period.

\subsection{Macro-Level Data}

Cross-border credit. To analyze the effects of credit market fragmentation on firm-level credit constraints computed using SAFE data, we need semi-annual data on credit inflows into the euro area countries. We retrieve quarterly data and assign the average of the second and third quarter to 'wave 1' for each year. The average across the fourth quarter of the current year and first quarter of the following year is assigned to 'wave 2', such 
that both the firm-level and the macroeconomic information is timed equivalently.

In order to measure the direct effect of cross-border bank lending on the financing situation of firms, we need information on the inflows of credit to the private non-financial sector for each of the 11 euro area countries included in the sample; ideally this information would only concern SMEs. Unfortunately, sectoral breakdowns of cross-border banking data are still rather scarce. The data closest to our needs are available from the International Banking Statistics by the Bank for International Settlements (BIS). A detailed description of all variables and sources is in the Data Appendix. We use quarterly country-level information on international bank claims to the non-bank private sector from the Consolidated Banking Statistics. These claims comprise loans and securities of all banks reporting to the BIS, consolidated across each bank. Hence, inter-office positions are netted out. The non-bank private sector includes private firms and private households, as well as non-bank financial institutions like special purpose vehicles, insurance companies, money market funds and the like. To the best of our knowledge, data on cross-border bank credit to non-financial firms are currently not publicly available for our sample period. ${ }^{5}$ Thus, we take international bank claims against the private non-bank sector from the Consolidated Banking Statistics as a proxy.

Besides the direct effects of cross-border lending, a retrenchment in credit market integration can impact the financing conditions of firms indirectly; for example via the funding situation of lenders. In order to evaluate the effects of cross-border credit on financing constraints of SMEs in a broader sense, we use BIS data on total international bank claims, as well as international claims on banks from the Consolidated Banking Statistics. Total international bank claims comprise cross-border claims of all reporting banks against all counterparties (banks, non-bank private sector, public sector) in the destination country, plus local claims of banks' foreign affiliates in foreign currency. Given that the BIS data is published in current USD, we transform the series into EUR using nominal exchange rates from the International Financial Statistics (IFS) and deflate using consumer price indexes from the IFS to obtain real cross-border bank claims.

Domestic credit. In addition to cross-border credit, we use data on domestic lending as an explanatory variable. Giannetti and Laeven (2012) present evidence for a "flight home" effect during the global financial crisis: Banks withdrew capital from abroad and tilted their loan portfolio more toward domestic lending - independent of the fundamentals in the home country. Due to the ongoing deleveraging and potential financial protectionism, this focus on domestic credit markets may persist in the aftermath of the crisis. Thus, the

\footnotetext{
${ }^{5}$ However, the BIS has started to provide such information for the most recent quarters.
} 
reduction in cross-border lending since the crisis may have been compensated in different euro area countries, at least partially, by increased domestic lending.

To control for such changes in the lending behavior of banks, we include domestic bank credit to the private non-financial sector from the BIS in the regression model. Again, this series includes domestic credit to private non-financial corporations, but also to private households and non-profit institutions serving households (NPISHs).

Total credit to the private non-financial corporations. In order to evaluate how changes in loan rates are affected by overall credit, we use The Statistics on Credit to the Private Non-Financial Sector by the BIS. The dataset provides information on total credit from all sources, i.e. independent of the type or country of origin of the lender. Total credit data are available for the entire private non-financial sector (non-financial corporations, households, and NPISHs), as well as for private non-financial corporations at quarterly frequency. We use the latter series here.

Figure 4 plots the semi-annual growth rates of the different credit aggregates. In the aftermath of the crisis, (real) credit to the private sector declined, on average, in our sample of 11 euro area countries. The upper panel reveals that, on average, domestic banks have significantly reduced their lending to the private sector - the reductions, as measured by log-differences, are more pronounced than the reductions in total credit to the private sector. When looking at the growth rates of cross-border credit, it appears that euro area credit markets became increasingly segmented through the beginning of 2013. In particular, cross-border claims on banks in the euro area economies were reduced. This decline in wholesale funding possibilities of euro area banks has contributed to the reduction in domestic bank credit. At the end of 2013, a modest increase in cross-border interbank lending could be observed.

\subsection{Regression Model}

In order to analyze how credit market segmentation in the euro area affects the external financing costs of SMEs, we proceed as follows. In a first step, we use a linked micro-macro dataset to estimate a pooled probit model where the dependent variable equals one if a firm has experienced an increase in its lending rates and zero otherwise. Our explanatory variables of interest are different credit aggregates. We evaluate the effect of changes in total credit to non-financial firms and then consider the effects of changes in domestic and cross-border bank credit separately. The correlogram of the different credit measures (Table 4) reveals that international bank credit and domestic bank credit to the private sector are positively (and statistically significantly) correlated in our sample of 11 euro 
area countries, with a correlation coefficient of .31. This may be a first hint at the indirect channel of international credit market fragmentation: a contraction in cross-border credit may come with a contraction in domestic bank credit. Moreover, total international credit is more closely related to movements in cross-border credit to banks than to non-banks, reflecting the importance of the international interbank linkages of European banks.

Credit market segmentation and the financing cost of firms. Using the micromacro data set described above, we model the probability of a firm seeing its loan rate increase as follows:

$$
\operatorname{Pr}\left[R_{i s c t}=1\right]=\alpha_{c}+\theta_{s}+\lambda_{t}+\beta_{1} \text { ForCred }_{c t}+\beta_{2} \text { DomCred }_{c t}+\gamma Z_{c t}+\xi X_{i s c t}+\epsilon_{i s c t}
$$

where $R_{\text {isct }}$ is a dichotomous variable that equals one if firm $i$ in country $c$ and sector $s$ reports a loan rate increase at time $t$, and zero otherwise, ForCred Ft $_{\text {is }}$ is the growth rate of cross-border credit, and DomCred $_{c t}$ is the growth rate of domestic bank credit to the private sector. $Z_{c t}$ is a set of macroeconomic control variables, and $X_{i s c t}$ is a set of firm covariates to control for observable firm-level heterogeneity. In addition, country dummies $\left(\alpha_{c}\right)$, sector $\left(\theta_{s}\right)$, and time dummies $\left(\lambda_{t}\right)$ are included in each regression to control for time-invariant country and sector characteristics as well as for common time trends in the data. Note that we cannot include firm-level fixed effects as many firms report to SAFE just once. Dropping all these firms would significantly reduce our sample size. Therefore, we estimate Eq.(1) using a pooled probit model.

Following the literature, we control for borrower characteristics using information on firm size, age, turnover, and ownership structure from SAFE. According to previous findings, we expect a negative link between credit costs and firm size, age, and turnover. Concerning ownership, firms owned by other firms or by shareholders are expected to be less credit constrained than those owned by an individual entrepreneur or a family.

As we are interested in the effect of a reduction in cross-border credit supply on firms' loan rates, one important challenge here is to control for changes in firms' loan demand. If loan demand of firm $i$ increases and this is not controlled for, loan rates may increase (the loan demand curve shifts out), and our estimates are biased upwards. By contrast, if loan demand is not controlled for and declines, loan rates tend to decline (as loan demand shifts inwards) so that our estimates are biased downwards. Following Banerjee (2014), we include a control variable related to firms' loan demand, namely a dummy variable that equals one if a firm's most pressing problem is to find customers. The idea is that firms should have a lower demand for new credit - and hence a lower likelihood of seeing their credit conditions tightening - if they have difficulty in selling their products. We 
also include dummies indicating the sector the firm operates in (Construction, Industry, Services, Trade) in all regressions, because the previous literature shows that the firms' need for external financing varies significantly by sector (e.g. Rajan and Zingales 1998, Friedrich et al. 2013). In the robustness tests below, we also include sector-time dummies to control for changes in loan demand at the sector-level.

In terms of macroeconomic control variables, we include aggregate deposit rates, countries' interbank dependence, and the change in the number of banks in order to control for common banking system characteristics. All these variables are retrieved from the ECB Data Warehouse. We expect a higher probability of a loan rate increase for firms in countries with higher deposit rates, a higher degree of interbank dependence, and a larger reduction in the number of banks. Moreover, we add an indicator of economic risk. As banks have adjusted their risk perceptions in the realm of the crisis, this may imply that they charged higher risk premia and, hence, loan rates for SME loans. The economic risk indicator is available from the International Country Risk Guide, a proprietary database that is also used by firms and banks to assess business risks. It includes information on GDP per capita, GDP growth, inflation, as well as the budget balance and the current account relative to GDP. In addition, we include 5-year sovereign credit default swap (CDS) spreads to control for differences in sovereign risk, given that our sample period includes the European sovereign debt crisis. These data are retrieved from Thomson Reuters Datastream. ${ }^{6}$ Table 5 presents summary statistics for all variables included in the regression sample.

One problem with this type of micro-macro data and the non-linear probit regression model is determining the appropriate level at which to cluster standard errors. The observational unit in our data set is the firm, which is nested within sectors and countries. Ideally, we would like to cluster at the broadest level, i.e. the country level. However, cluster-robust estimation relies on the number of clusters going to infinity (Cameron and Miller 2015). As the number of countries in our sample is small (as is the number of sectors), we cluster at the firm level. Yet, in robustness tests, we check how the significance of our results is affected when clustering at the country level.

Running a simple pooled probit model on firms' loan conditions means that we look at firms that actually applied for and were granted credit. This implies a non-random

\footnotetext{
${ }^{6}$ We also added net interest margins, financial risk, and the ratio of total credit to the private sector relative to GDP to all regressions. Credit to GDP is often used as a measure of financial development in large country samples. Yet, it is also a measure of the degree of debt financing and, hence, leverage in an economy. Yet, including theses additional macro-variables leads to a very high degree of multicollinearity. That is why we opt for the more parsimonious specification here.
} 
selection of firms into our regression sample, leading to potentially biased estimates. Firms that did not apply for a loan - either because they were discouraged or because they did not need a new loan - may have seen larger increases in loan rates than firms that received new credit, e.g. due to high fixed costs of using bank credit. In order to take this potential downward bias of our estimates into account, we also estimate a probit model with Heckman selection.

Similar to Popov and Udell (2012) and Beck et al. (2014), we model a firm's decision to participate in the credit market using a dichotomous variable that equals one if a firm has applied for a loan and zero otherwise. In the first-stage selection equation of the Heckman procedure, we regress this dichotomous loan application variable on all regressors included in the baseline Eq.(1), and on additional variables, as required by the exclusion restriction. The first additional variable equals one if a firm reports its most pressing problem to be competition, and zero otherwise. The second variable takes on a value of one if a firm's most pressing problem is high labor input costs. For both variables, we expect a negative relation with loan applications.

Differential effects: The role of firm size. In addition to estimating Eq.(1) with the probit approaches discussed above, we analyze whether firms of different size are affected differently by credit market fragmentation. To that aim, we interact all credit variables with an indicator variable that equals one if a firms has more than 50 employees $\left(\right.$ Size $\left.50_{i s c t}\right)$, and is, hence, classified as a medium-sized firm, and zero otherwise:

$$
\begin{aligned}
\operatorname{Pr}\left[R_{i s c t}=1\right] & =\alpha_{c}+\theta_{s}+\lambda_{t}+\beta_{1} \text { ForCred }_{c t}+\beta_{2} \text { DomCred }_{c t} \\
& +\beta_{3} \text { ForCred }_{c t} \cdot{\text { Size } 50_{i s c t}+\beta_{4} \text { DomCred }_{c t} \cdot{\text { Size } 50_{i s c t}}_{i s t}}+\gamma Z_{c t}+\xi X_{i s c t}+\epsilon_{i s c t}
\end{aligned}
$$

Even if larger firms are expected to have more favorable financing conditions than smaller firms that are inherently more opaque and risky, credit market fragmentation may affect the larger firms in our sample more than smaller ones due to potential direct linkages to foreign banks or larger reliance on bank credit in general. 


\section{Estimation Results}

\subsection{Credit Growth and Financing Costs of SMEs}

Before coming to the effects of credit market fragmentation on loan rate increases for SMEs, let us look at the first-stage selection equation. Table 6 reveals that larger firms (both in terms of employees and turnover) are more likely to apply for a loan than smaller ones. Furthermore, firms that are owned by shareholders are less likely to apply for a bank loan, probably due to the fact that they can resort to other means of financing. As expected, firms facing strong competition, high labor costs, or weak demand for their products are less likely to apply for credit. Turning to the macroeconomic control variables, we find that firms in countries with a higher interbank dependence are more likely to send out a loan application. We also find some evidence that firms in countries with higher CDS spreads are less likely to apply for loans.

Table 7 presents the regression results for the increase in loan rates as the dependent variable. Larger firms, firms owned by shareholders, and firms that have great difficulty in finding customers are less likely to experience loan rate rises. Older firms tend to be more likely to see loan rate increases. Regarding the macroeconomic drivers of firms' credit costs, firms from countries with higher interbank dependence are more likely to experience loan rate increases. As expected, the higher the average deposit rate and, hence, bank's funding costs or the higher the economic risk at the country-level, the higher the probability of a loan rate increase for a given firm. The larger the reduction in the number of banks serving a firm's home country and, hence, the lower contestability in the credit market, the higher is the probability of a loan rate increase.

Regarding the different credit measures, we find that larger reductions in total credit to non-financial firms make loan rate increases more likely - both in the probit model and in the model with Heckmann selection (columns 1 and 2). When considering domestic and cross-border credit separately, we find that only international bank credit growth has a negative and statistically significant impact on the likelihood of increasing loan rates for SMEs. The direct effect of domestic credit growth is statistically insignificant. Columns 5 and 6 reveals that the negative effect of cross-border credit is driven by cross-border bank loans: the stronger the reduction in cross-border credit to banks, the higher the probability of increasing loan rates. By contrast, changes in cross-border credit to nonbanks do not seem to matter for changes in the financing costs of SMEs. This may be due to the fact that direct foreign lending is less important for SMEs' external financing 
situation than lending by domestic banks. ${ }^{7}$ Thus, credit market fragmentation in the interbank market seems to have a more detrimental effect on the financing costs of SMEs than the reduction in direct cross-border lending to firms. This finding is in line with the empirical results of Iyer et al. (2014) for Portugal.

Table 8 presents the regression results for interactions between the credit variables and a dummy variable that equals one for firms with more than 50 employees. Again, the relation between credit growth and firms' likelihood of loan rate increases is negative and statistically significant. For the larger firms in our sample, the negative impact of a reduction in total credit and in total international credit is larger than for the smaller firms. Moreover, larger firms are more likely to experience higher borrowing costs, the stronger is the reduction in cross-border credit to their home country banks. The effects of credit market segmentation might be more pronounced for larger firms as the latter typically receive more (cross-border) credit than the smaller firms.

\subsection{Economic Significance}

In order to get an idea about the magnitudes of the above identified linkages between credit growth and the probability of loan rate increases, we now discuss and interpret the marginal effects from our regressions in greater detail. Given that the probit estimator is non-linear, the marginal effects of the independent variables in the model are nonconstant. They vary with changes in the predictors.

When considering an average firm in an average credit market (all variables are set at their sample means), our results indicate that the probability of a loan rate increase faced by this firm is $65 \%$ in the 2010 - 2014 period(based on the model from column (2), Table 7). ${ }^{8}$ Yet, this probability rises by 7 percentage points, up to $72 \%$, if total credit growth is at the sample minimum (-.07) and all other predictors remain at the sample means. If total credit growth is at its maximum (.04), the probability of an average firm seeing its loan rate increase drops to $60 \%$ though. Overall, the probability of facing higher loan rates varies by 12 percentage points, depending on total credit growth in the country the firm operates in.

Repeating the same exercise for the effect of international credit growth, our results

\footnotetext{
${ }^{7}$ Moreover, this credit aggregate includes not only cross-boder credit to SMEs, but also to non-bank financials and households, for example.

${ }^{8}$ We base our discussion of marginal effects on our preferred regression setup with Heckman selection here. However, the results based on the simple probit model are qualitatively the same.
} 
indicate even larger effects: Here, the difference between the likelihood of loan rate increases in countries with the highest (.23) and the lowest growth (-.32) in international credit is 15 percentage points. Thus, the effect of a retrenchment in international credit on firms' loan rates is not only statistically, but also economically meaningful. Further, when comparing these marginal effects to those of firm-level characteristics, the impact of credit growth is important. For example, when computing marginal effects across the different classes of turnover and keeping all other variables at their sampl means, the probability of firm-level loan rate increases varies between 64 and $66 \%$ only.

Figure 5 plots average adjusted predictions (AAPs) for different credit aggregates, based on the regression models using the Heckman selection approach. It illustrates that the probability of firms seeing their loan rates increase is higher, the larger the reduction in credit is - both for total and for the different international credit variables.

\subsection{Robustness Tests}

We run several alternative regressions in order to test the robustness of the results discussed above. Table 9 shows that adding a control group for large firms, i.e. firms with more than 250 employees, does not weaken our main results. Rather, it strengthens the result that the retrenchment in cross-border bank credit negatively affects, in particular, larger firms' cost of credit in the sample. Furthermore, dropping individual firm-level variables from the model or including a set of sector-and-time dummies does not affect our results. ${ }^{9}$ Moreover, when clustering robust standard errors at the country level instead of at the firm level, our results remain statistically significant. Changes in inflation are not explicitly considered by firms reporting loan rate changes. In order to rule out that our results are driven by changes in inflation, we include CPI inflation as an additional regressor. As expected, the estimation results reveal that if inflation rises, nominal interest rates on new loans are more likely to also rise, although the results are mostly not statistically significant. Still, the introduction of CPI inflation in the regression model does not alter our previous findings.

Second, we run ordered probit regressions where the dependent categorical variable is assigned a value of 1 if a firm's loan rate decreased over the past six months, a value of 2 if the loan rate was unchanged, and a value of 3 if the loan rate increased. The ordered probit regressions support our previous results that reductions in aggregate credit make

\footnotetext{
${ }^{9}$ We do not report all the robustness tests. The respective tables are available from the authors upon request.
} 
loan rate increases more likely (and loan rate reductions less likely). Moreover, in this setup, the relationship between cross-border credit to non-banks and the likelihood of loan rate increases at the firm-level is negative and statistically significant. Hence, when differentiating between positive and negative loan rate changes, the estimation results suggest that fragmentation in the international market for credit to non-banks coincides with increased external financing costs for SMEs - even if direct foreign credit is not as important for SMEs as domestic credit.

Third, we aggregate SAFE-data for each country at the sector-level and estimate the following aggregate version of Eq.(1) using a fractional probit model, where the dependent variable is bound between zero and one:

$$
\text { Share }_{\text {sct }}=\alpha_{c}+\theta_{s}+\lambda_{t}+v_{s t}+\beta_{1} \text { ForCred }_{c t}+\beta_{2} \text { DomCred }_{c t}+\gamma Z_{c t}+\epsilon_{\text {sct }}
$$

Share $R_{\text {sct }}$ is the share of firms in sector $s$ and country $c$ at time $t$ that reported a loan rate increase. All time-varying, sector-specific factors, like changes in credit demand or sectoral business conditions, are controlled for by sector-time fixed effects $\left(v_{s t}\right)$. As in the baseline specification, we also add sector, time, and country fixed effects. Apart from this, we include the same time-varying country-level variables as in the baseline regressions.

While some of the macroeconomic control variables do not significantly affect the sectoral share of firms with higher financing costs, Table 10 confirms our previous results that a retrenchment in international credit leads to a deterioration of firms' borrowing costs. The sectoral version of the regression model corroborates the role of the interbank channel for firms' financing costs.

Finally, we evaluate endogeneity issues. Our findings point to a negative link between aggregate credit growth and the probability of loan rate increases at the firm-level. It is unlikely that this result is driven by reverse causality, because increasing loan rates in a destination country of credit should make it more attractive for banks to lend. Thus, we would expect the effect of loan rate increases on credit growth to be positive or insignificant. Moreover, individual firm-level developments should not drive aggregate variables (Langfield and Pagano 2015), especially when looking at small firms.

Potential instrumental variables for cross-border credit, like changes in the regulation of foreign bank entry, institutional changes, or creditor rights, are very similar in the countries considered here and do not vary much across the period 2010-2014. Still, we check whether categorical variables measuring the implementation of stricter capital and other regulatory requirements, taken from the prudential policy database developed by Cerutti et al. (2016), could be used to instrument aggregate credit variables in our sample. 
After selecting those potential instruments that do not seem to suffer from a weak instruments problem, we test for the exogeneity of the potentially endogenous credit aggregates. Yet, we cannot reject the null hypothesis of exogeneity, so that the probit model without instrumenting aggregate credit is the preferred specification here.

\section{Conclusions}

The aim of this paper is to shed light on real consequences of credit market fragmentation in the euro area since the crisis. SMEs in the euro area continue to receive special attention from policy makers, not least with regard to the design of the Capital Markets Union (CMU), as they were hit the hardest by the credit crunch during the crisis.

So far, the literature on the financing constraints of firms in the euro area concentrates on the importance of firm characteristics for credit conditions of firms. Yet, how the structural changes in cross-border banking affect the access of SMEs to finance is not yet investigated. This study is a first step in filling this gap. Using a linked micro-macro panel data set, we examine the link between the retrenchment in cross-border bank lending and the evolution of financing costs for SMEs in the euro area.

Our paper has three main findings. First, we find that reductions in cross-border bank lending made loan rate increases for SMEs more likely. The effects are meaningful, both in statistical and in economic senses. For firms in countries with the strongest reductions in international credit, the probability of facing higher loan rates is 15 percentage points higher than for firms in countries with the most favorable evolution of international credit. Second, the larger the retrenchment in cross-border lending to banks was, the higher the likelihood that SMEs saw their credit costs rise. Thus, the negative link between total cross-border credit growth and the financing costs for firms seems to be driven by the interbank lending channel. Yet, we do not find a significant and consistent effect of direct cross-border lending to non-banks on SMEs financing costs. Third, we can show that, in particular, the larger European enterprises included here have suffered from the fragmentation of international credit markets.

Overall, our results show that cross-border lending does indeed affect the access to finance for SMEs, though mostly indirectly through the interbank channel. To alleviate financing constraints for SMEs, one important factor is thus credit market integration. 


\section{References}

Almeida, Heitor, Murillo Campello, and Michael S Weisbach, "The Cash Flow Sensitivity of Cash," Journal of Finance, 2004, 59 (4), 1777-1804.

Altomonte, Carlo and Tommaso Aquilante, "The EU-EFIGE/Bruegel-Unicredit dataset," Working Papers 753, Bruegel October 2012.

Artola, Concha and Veronique Genre, "Euro Area SMEs under Financial Constraints: Belief or Reality?," CESifo Working Paper Series 3650, CESifo Group Munich 2011.

Banerjee, Ryan, "SMEs, Financial Constraints and Growth," BIS Working Papers No 475, December 2014.

Baskaya, Soner, Julian di Giovanni, Sebnem Kalemli-Ozcan, Jose-Luis Peydro, and Mehmet Ulu, "Capital Flows and International Credit Channel," Journal of International Economics, 2017, forthcoming.

Baum, Christopher F, Dorothea Schäfer, and Oleksandr Talavera, "The Impact of the Financial System's Structure on Firms' Financial Constraints," Journal of International Money and Finance, 2011, 30 (4), 678-691.

Beck, Thorsten, Asli Demirgüç-Kunt, and María Pería, "Bank Financing for SMEs: Evidence Across Countries and Bank Ownership Types," Journal of Financial Services Research, April 2011, 39 (1), 35-54.

_, Asli Demirguc-Kunt, and Maria Soledad Martinez Peria, "Bank Financing for SMEs Around the World," Research Working Papers, 2008, 1 (1), 1-43.

_, _, Luc Laeven, and Vojislav Maksimovic, "The Determinants of Financing Obstacles," Journal of International Money and Finance, October 2006, 25 (6), 932952.

_ , Hans Degryse, Ralph De Haas, and Neeltje van Horen, "When Arm's Length Is too Far: Relationship Banking over the Business Cycle," BOFIT Discussion Papers 14/2014, Bank of Finland, Institute for Economies in Transition July 2014.

Berger, Allen N., Leora F. Klapper, and Gregory F. Udell, "The Ability of Banks to Lend to Informationally Opaque Small Businesses," Journal of Banking $\&$ Finance, December 2001, 25 (12), 2127-2167. 
Brei, Michael, "The Impact of a Sudden Stop on Bank Lending," Social and Economic Studies, 2007, 56 (4), 21-45.

Bremus, Franziska and Marcel Fratzscher, "Drivers of structural change in crossborder banking since the global financial crisis," Journal of International Money and Finance, 2015, 52, 32-59.

Bremus, Franziska M., "Cross-Border Banking, Bank Market Structures and Market Power: Theory and Cross-Country Evidence," Journal of Banking \& Finance, 2015, 50 (C), 242-259.

Bruno, Valentina and Hyun Song Shin, "Capital Flows, Cross-Border Banking and Global Liquidity," NBER Working Papers 19038, National Bureau of Economic Research, Inc May 2013.

Cameron, A Colin and Douglas L Miller, "A Practitioner's Guide to Cluster-Robust Inference," Journal of Human Resources, 2015, forthcoming, 221-236.

Cerutti, M. E. M., M. R. Correa, E. Fiorentino, and E. Segalla, "Changes in Prudential Policy Instruments - A New Cross-Country Database," IMF Working Paper $W P / 16 / 110$, June 2016.

Cetorelli, Nicola and Linda S Goldberg, "Global Banks and International Shock Transmission: Evidence from the Crisis," IMF Economic Review, April 2011, 59 (1), $41-76$.

Clarke, George R. G., Robert Cull, and Maria Soledad Martinez Peria, "Does Foreign Bank Penetration Reduce Access to Credit in Developing Countries? Evidence from Asking Borrowers," Policy Research Working Paper Series 2716, The World Bank November 2001.

Clarke, George, Robert Cull, Maria Soledad Martinez Peria, and Susana M Sanchez, "Bank Lending to Small Businesses in Latin America: Does Bank Origin Matter?," Journal of Money, Credit and Banking, February 2005, 37 (1), 83-118.

Coluzzi, Chiara, Annalisa Ferrando, and Carmen Martinez-Carrascal, "Financing Obstacles and Growth: An Analysis for Euro Area Non-Financial Firms," European Journal of Finance, 2012, (ahead-of-print), 1-18.

de Blas, Beatriz and Katheryn Niles Russ, "All Banks Great, Small, and Global: Loan Pricing and Foreign Competition," International Review of Economics 85 Finance, 2013, 26 (C), 4-24. 
ECB, "Survey on the Access to Finance of SMEs: User Guide for the Anonymised Dataset," Technical Report Version: 28 March 2014, European Central Bank, Frankfurt/Main 2014.

Fazzari, Steven M. and Bruce C. Petersen, "Working Capital and Fixed Investment: New Evidence on Financing Constraints," RAND Journal of Economics, Autumn 1993, $24(3), 328-342$.

Ferrando, Annalisa and Klaas Mulier, "Firms' Financing Constraints: Do Perceptions Match the Actual Situation?," Economic and Social Review, 2015, 46 (1), 87 117.

- and Nicolas Griesshaber, "Financing Obstacles among Euro Area Firms: Who Suffers the Most?," Working Paper Series 1293, European Central Bank February 2011.

Feyen, Erik, Raquel Letelier, Inessa Love, Samuel Munzele Maimbo, and Roberto Rocha, "The Impact of Funding Models and Foreign Bank Ownership on Bank Credit Growth : Is Central and Eastern Europe Different?," Policy Research Working Paper Series 6783, The World Bank February 2014.

Forbes, Kristin J., "One Cost of the Chilean Capital Controls: Increased Financial Constraints for Smaller Traded Firms," Journal of International Economics, April 2007, 71 (2), 294-323.

Friedrich, Christian, Isabel Schnabel, and Jeromin Zettelmeyer, "Financial Integration and Growth: Why is Emerging Europe Different?," Journal of International Economics, 2013, 89 (2), 522-538.

Gallego, Francisco and Norman Loayza, "Financial Structure in Chile: Macroeconomic Developments and Microeconomic Effects," in A. Demirgüç-Kunt and R. Levine, eds., Financial Structure and Economic Growth, Cambridge, MA, MIT Press, 2001, pp. 299-346.

Gelos, R. Gaston and Alejandro M. Werner, "Financial Liberalization, Credit Constraints, and Collateral: Investment in the Mexican Manufacturing Sector," Journal of Development Economics, February 2002, 67 (1), 1-27.

Giannetti, Mariassunta and Luc Laeven, "The Flight Home Effect: Evidence from the Syndicated Loan Market during Financial Crises," Journal of Financial Economics, 2012, 104 (1), 23-43. 
- and Steven Ongena, "Financial Integration and Firm Performance: Evidence from Foreign Bank Entry in Emerging Markets," Review of Finance, 2009, 13 (2), 181-223.

Harris, John R, Fabio Schiantarelli, and Miranda G Siregar, "The Effect of Financial Liberalization on the Capital Structure and Investment Decisions of Indonesian Manufacturing Establishments," World Bank Economic Review, January 1994, 8 (1), $17-47$.

Holton, Sarah, Martina Lawless, and Fergal McCann, "Firm Credit in the Euro Area: A Tale of Three Crises," Applied Economics, January 2014, 46 (2), 190-211.

Iyer, Rajkamal, José-Luis Peydró, Samuel da Rocha-Lopes, and Antoinette Schoar, "Interbank Liquidity Crunch and the Firm Credit Crunch: Evidence from the 2007-2009 Crisis," Review of Financial Studies, 2014, 27 (1), 347-372.

Kaplan, Steven N. and Luigi Zingales, "Do Financing Constraints Explain Why Investment Is Correlated with Cash Flow?," Quarterly Journal of Economics, 1997, 112, 169-216.

_ and _ , "Investment-Cash Flow Sensitivities Are Not Valid Measures Of Financing Constraints," Quarterly Journal of Economics, May 2000, 115 (2), 707-712.

Laeven, Luc, "Does Financial Liberalization Reduce Financing Constraints?," Financial Management, Winter 2002, 31 (4), 5-34.

Lane, Philip, "Financial Globalisation and the Crisis," Open Economies Review, July 2013, 24 (3), 555-580.

_ , "Capital Flows in Low-Income Countries," Paper prepared for the Conference on "Macroeconomic Challenges Facing Low-Income Countries" held at the IMF, January 30-31, Washington, D.C. 2014a.

_ , "Cross-Border Financial Linkages: Identifying and Measuring Vulnerabilities," Technical Report, CEPR Policy Insight No. 77 2014b.

Langfield and Pagano, "Bank Bias in Europe: Effects on Systemic Risk and Growth," Technical Report, ECB Working Paper No. 1797 May 2015.

Mian, Atif, "Distance Constraints: The Limits of Foreign Lending in Poor Economies," Journal of Finance, 06 2006, 61 (3), 1465-1505. 
Milesi-Ferretti, Gian-Maria and Cédric Tille, "The Great Retrenchment: International Capital Flows during the Global Financial Crisis," Economic Policy, 04 2011, 26 (66), 285-342.

Popov, Alexander and Gregory F Udell, "Cross-Border Banking, Credit Access, and the Financial Crisis," Journal of International Economics, 2012, 87 (1), 147-161.

Rajan, Raghuram G and Luigi Zingales, "Financial Dependence and Growth," American Economic Review, 1998, 88 (3), 559-586.

Wehinger, Gert, "SMEs and the Credit Crunch: Current Financing Difficulties, Policy Measures and a Review of Literature," OECD Journal: Financial Market Trends, 2013, $2013(2), 115-148$. 


\section{Figures}

Figure 1: Change in the availability of bank loans for SMEs

This figure plots the net weighted percentage of responses (increased - decreased). The data are available from SAFE by the ECB. $W$ denotes the waves of the survey.

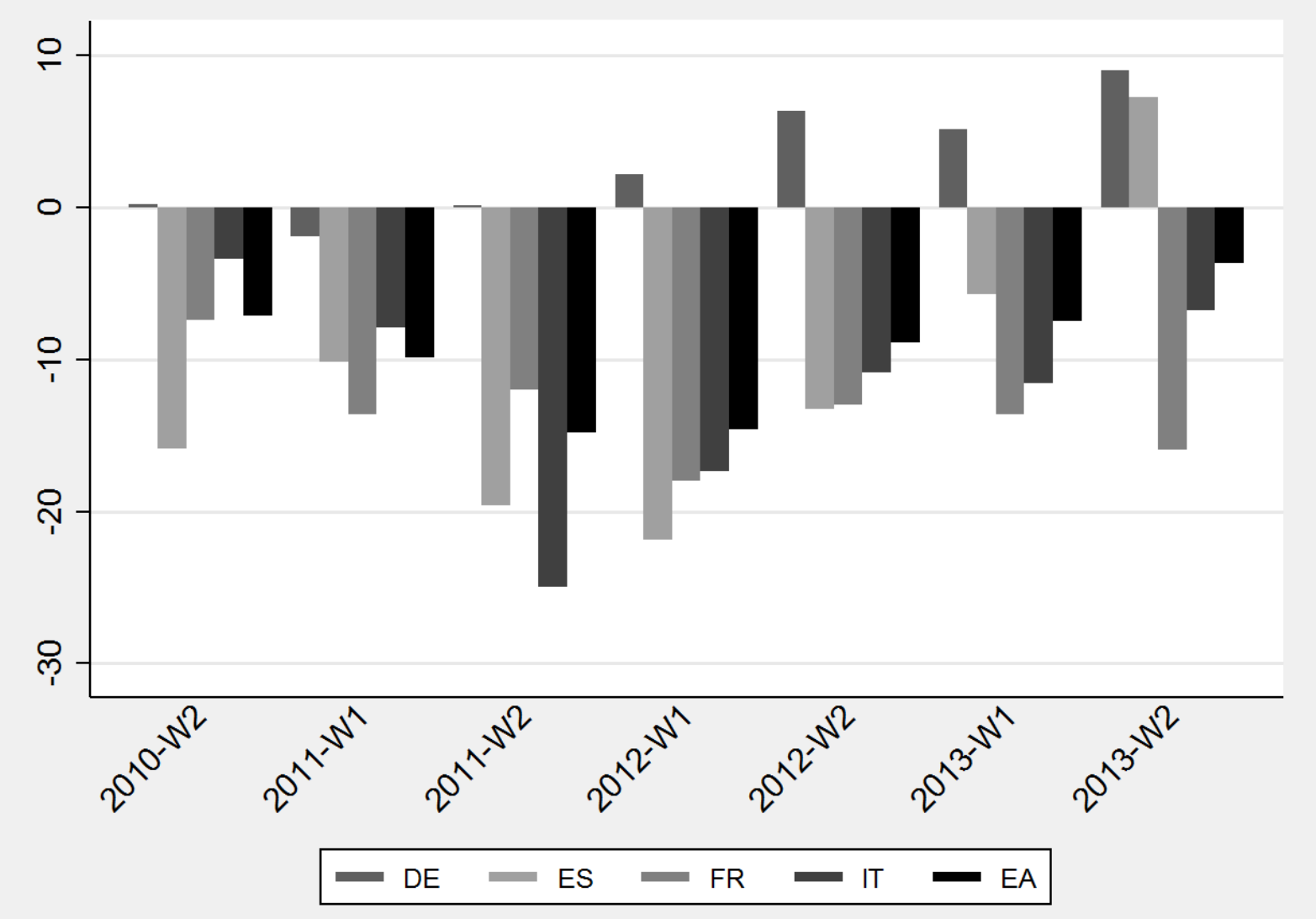


Figure 2: Loan rate spreads in the euro area

This figure plots the difference between interest rates on small and large loans (percentage points) in the euro area. The data are available from the MFI Interest Rate Statistics by the ECB.

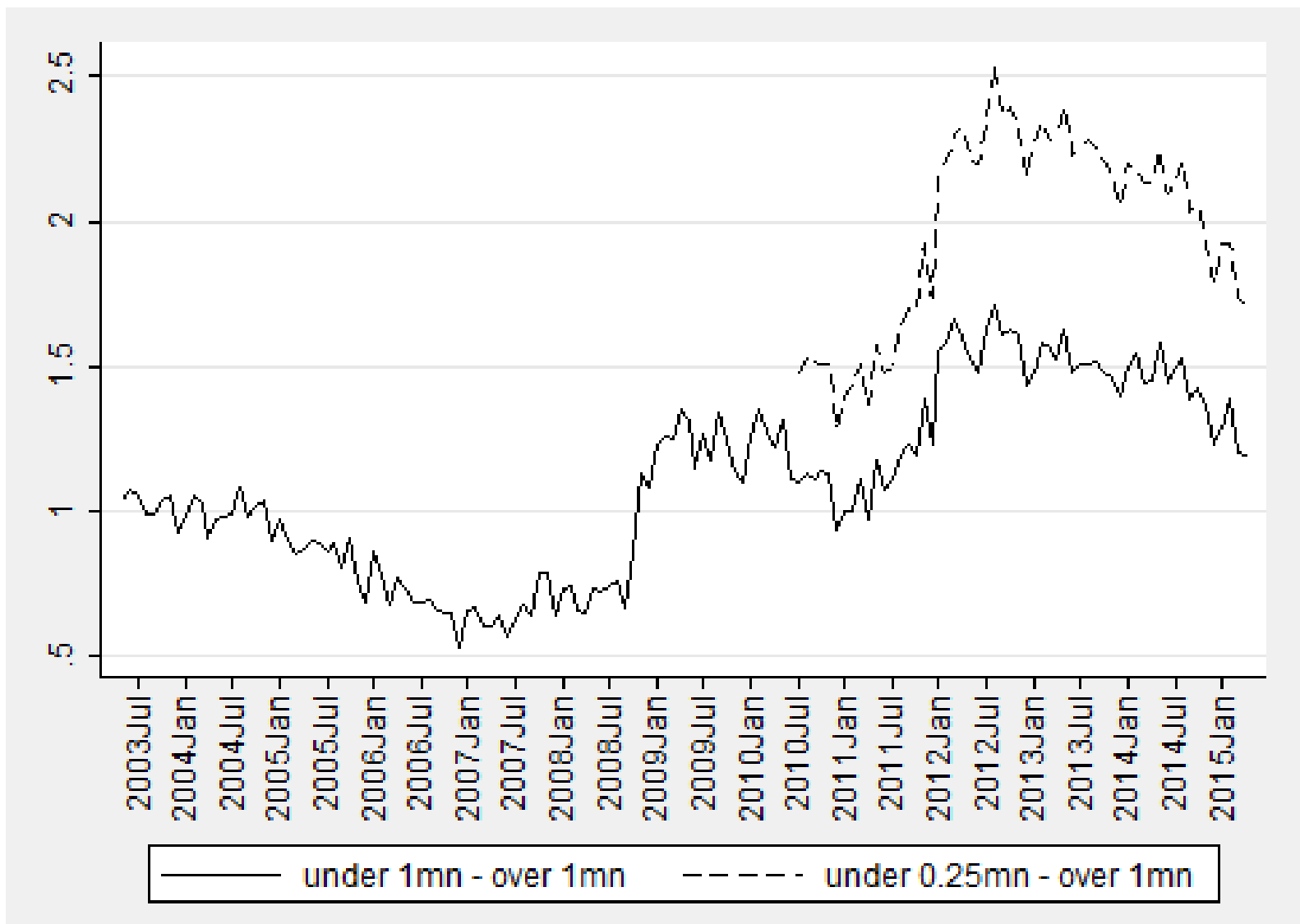


Figure 3: Firms' most pressing problem

This figure plots the most pressing problem named by firms in SAFE (weighted). The euro area sample includes the 11 countries used in this paper. Representative country-level results are available for France, Germany, Spain, and Italy.

DE

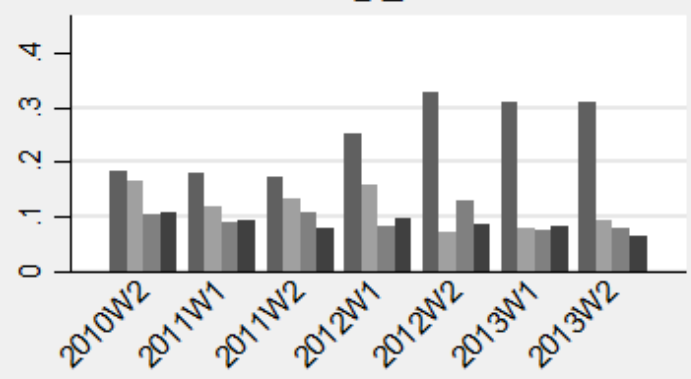

FR

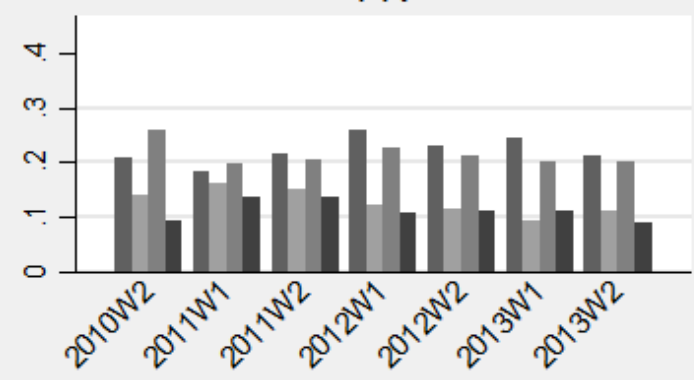

Euro area

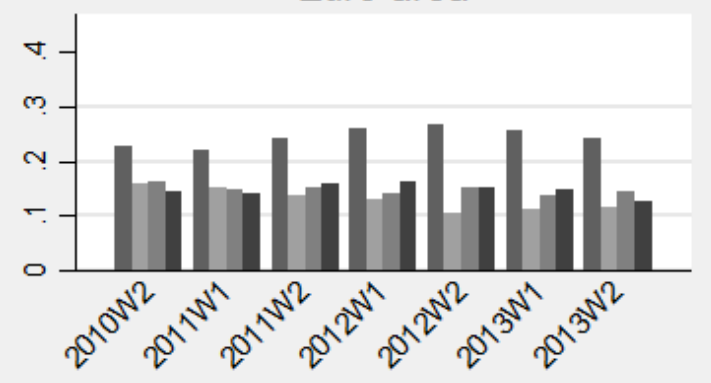

ES

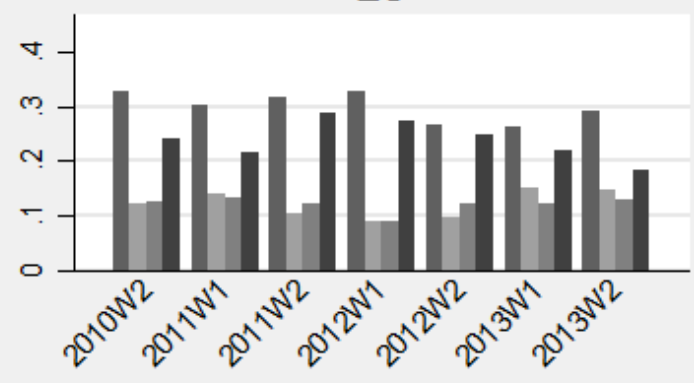

IT

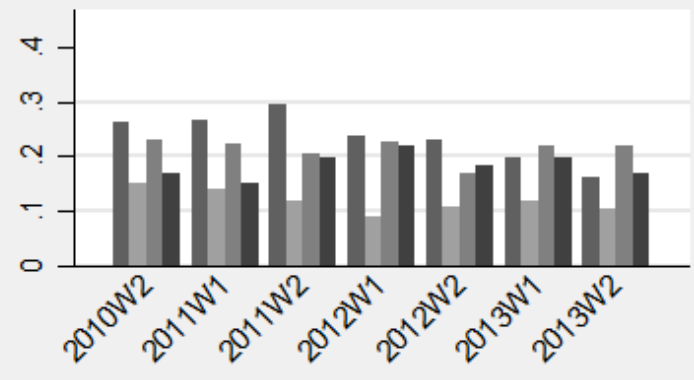

Finding customers 
Figure 4: Log-changes in real credit

This figure plots the sample means of the change in total, domestic and cross-border credit. All credit series are available from the BIS. The timing of the variables corresponds to the SAFE waves.

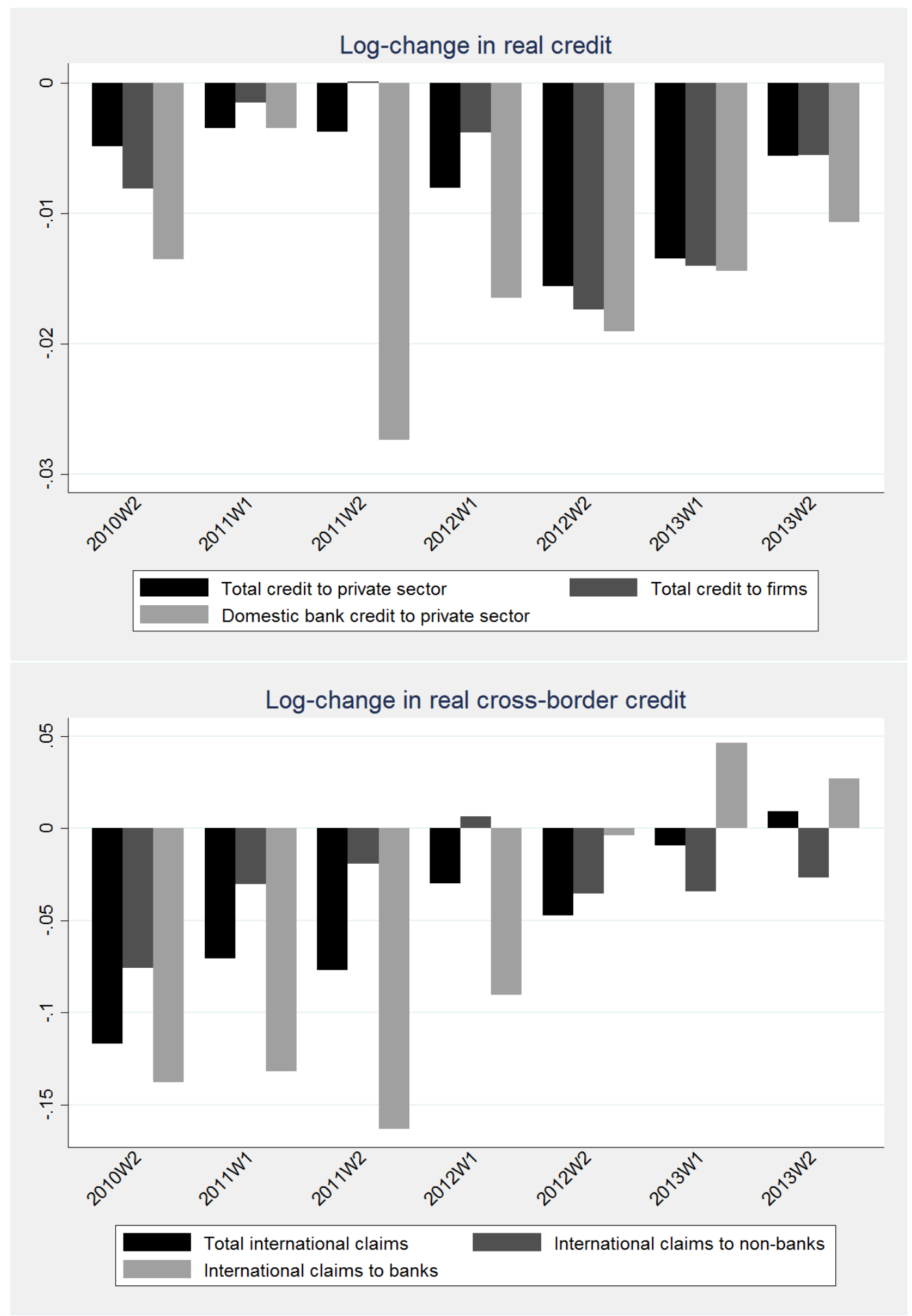


Figure 5: Marginal effects of credit growth

This figure plots the average adjusted predictions (AAPs) for different values of total and international credit growth, based on Table 7, columns (2) and (4), respectively. The gray areas reflect $95 \%$ confidence bands.

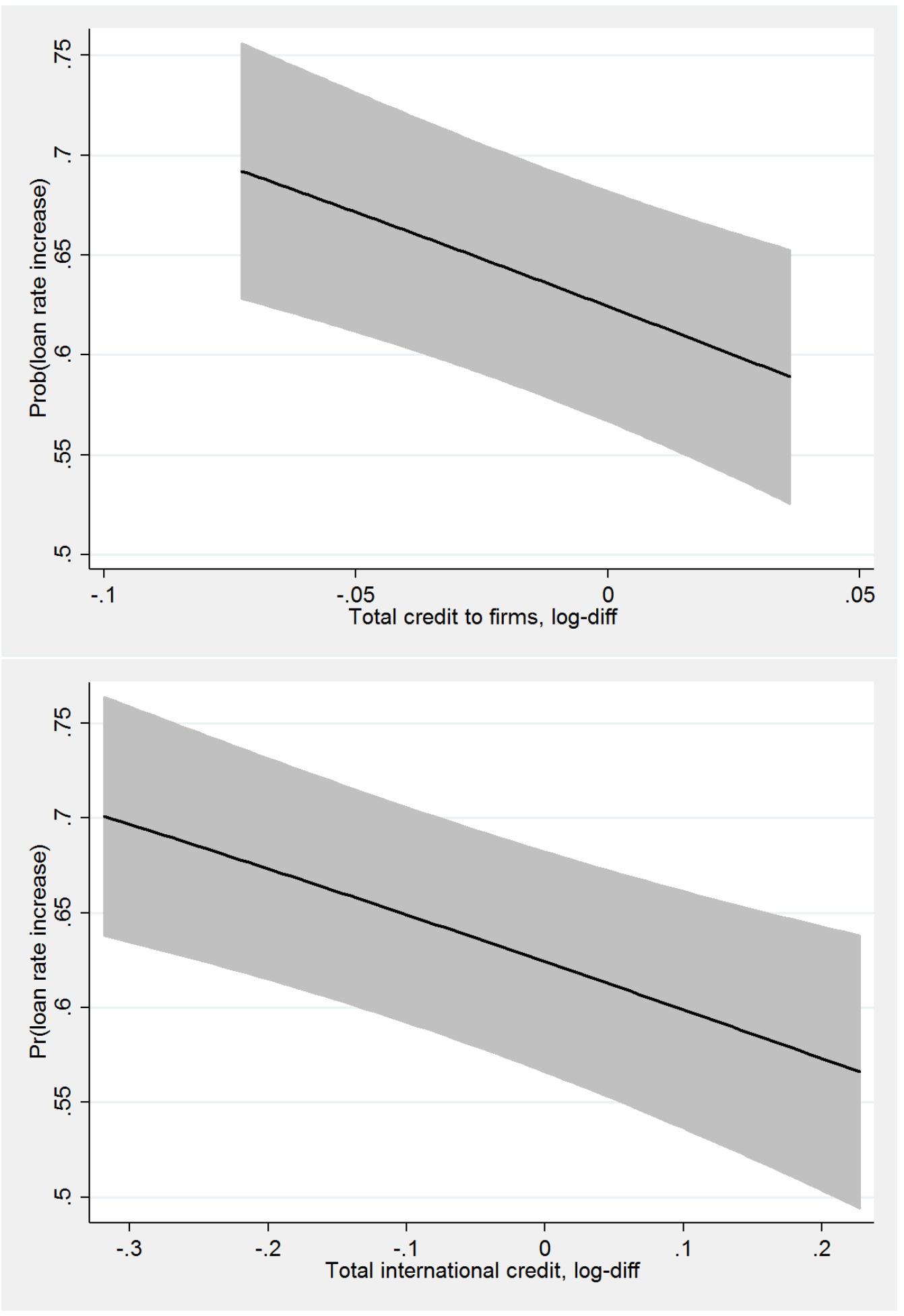




\section{Tables}

Table 1: SAFE country composition

This table gives the number of firms by year and wave in our sample.

\begin{tabular}{|c|c|c|c|c|c|c|c|}
\hline \multirow[b]{2}{*}{ Country } & \multicolumn{7}{|c|}{ Year and wave } \\
\hline & 2010W2 & 2011W1 & 2011W2 & $2012 W 1$ & 2012W2 & 2013W1 & 2013W2 \\
\hline Austria & 393 & 363 & 349 & 370 & 372 & 376 & 347 \\
\hline Belgium & 410 & 399 & 414 & 395 & 402 & 397 & 414 \\
\hline Germany & 792 & 661 & 683 & 711 & 641 & 649 & 644 \\
\hline Finland & 432 & 442 & 416 & 349 & 384 & 373 & 371 \\
\hline France & 784 & 774 & 760 & 767 & 736 & 762 & 783 \\
\hline Greece & 362 & 418 & 397 & 361 & 356 & 325 & 362 \\
\hline Ireland & 381 & 355 & 344 & 338 & 352 & 354 & 370 \\
\hline Italy & 753 & 685 & 659 & 734 & 621 & 686 & 655 \\
\hline Netherlands & 401 & 402 & 404 & 381 & 383 & 378 & 393 \\
\hline Portugal & 400 & 406 & 399 & 394 & 410 & 383 & 347 \\
\hline Spain & 721 & 706 & 699 & 709 & 699 & 705 & 699 \\
\hline Total & 5,829 & 5,611 & 5,524 & 5,509 & 5,356 & 5,388 & 5,385 \\
\hline
\end{tabular}


Table 2: Firm characteristics

This table gives the number of firms according to different firm characteristics provided by SAFE.

\begin{tabular}{lrr}
\hline & Frequency & Percent \\
\hline Employment (categories) & & \\
From 1 employee to 9 employees & 14,514 & 37.60 \\
From 10 employees to 49 employees & 14,533 & 37.65 \\
From 50 employees to 249 employees & 9,555 & 24.75 \\
& & \\
Main activity & & \\
Industry & 9,622 & 24.93 \\
Construction & 4,125 & 10.69 \\
Trade & 10,715 & 27.76 \\
Services & 14,140 & 36.63 \\
& & \\
Annual turnover & & \\
Up to $€ 2$ million & 21,031 & 54.48 \\
More than $€ 2$ million and up to $€ 10$ million & 11,213 & 29.05 \\
More than $€ 10$ million and up to $€ 50$ million & 6,358 & 16.47 \\
& & \\
Age of the firm & & \\
10 years or more & 30,556 & 79.16 \\
5 years or more but less than 10 years & 5,176 & 13.41 \\
2 years or more but less than 5 years & 2,409 & 6.24 \\
Less than 2 years & 461 & 1.19 \\
& & \\
Main owner of the firm & & \\
Public shareholders, as your company is & 1,109 & 2.87 \\
Family or entrepreneurs & 21,939 & 56.83 \\
Other firms or business associates & 3,915 & 10.14 \\
Venture capital firms or business angel & 443 & 1.15 \\
A natural person, one owner only & 10,564 & 27.37 \\
Other & 632 & 1.64 \\
\hline
\end{tabular}


Table 3: Loan rate increases by country and time

This table presents the share of firms that have experienced loan rate increases in our sample.

\begin{tabular}{lllllllll}
\hline \multicolumn{7}{c}{ Year and wave } \\
\hline Country & $2010 \mathrm{~W} 2$ & $2011 \mathrm{~W} 1$ & $2011 \mathrm{~W} 2$ & $2012 \mathrm{~W} 1$ & $2012 \mathrm{~W} 2$ & $2013 \mathrm{~W} 1$ & $2013 \mathrm{~W} 2$ & Total \\
& & & & & & & 0.27 & $\mathbf{0 . 3 7}$ \\
\hline Austria & 0.44 & 0.65 & 0.41 & 0.26 & 0.29 & 0.30 & 0.23 & $\mathbf{0 . 3 7}$ \\
Belgium & 0.57 & 0.47 & 0.42 & 0.35 & 0.26 & 0.30 & 0.52 & $\mathbf{0 . 4 9}$ \\
Finland & 0.46 & 0.30 & 0.26 & 0.44 & 0.60 & 0.77 & 0.21 & $\mathbf{0 . 3 4}$ \\
France & 0.46 & 0.59 & 0.51 & 0.23 & 0.17 & 0.19 & 0.08 & $\mathbf{0 . 2 0}$ \\
Germany & 0.37 & 0.44 & 0.16 & 0.16 & 0.10 & 0.13 & 0.34 & $\mathbf{0 . 6 7}$ \\
Greece & 0.81 & 0.84 & 0.81 & 0.66 & 0.47 & 0.55 & 0.34 & $\mathbf{0 . 5 7}$ \\
Ireland & 0.73 & 0.82 & 0.64 & 0.52 & 0.49 & 0.40 & 0.52 & $\mathbf{0 . 6 8}$ \\
Italy & 0.61 & 0.81 & 0.80 & 0.76 & 0.68 & 0.61 & 0.37 & $\mathbf{0 . 4 6}$ \\
Netherlands & 0.52 & 0.52 & 0.50 & 0.43 & 0.68 & 0.38 & 0.27 \\
Portugal & 0.79 & 0.75 & 0.70 & 0.72 & 0.58 & 0.55 & 0.27 & $\mathbf{0 . 6 2}$ \\
Spain & 0.85 & 0.87 & 0.85 & 0.78 & 0.80 & 0.72 & 0.45 & $\mathbf{0 . 7 7}$ \\
\hline Total & $\mathbf{0 . 5 7}$ & $\mathbf{0 . 6 6}$ & $\mathbf{0 . 5 5}$ & $\mathbf{0 . 4 6}$ & $\mathbf{0 . 4 0}$ & $\mathbf{0 . 3 8}$ & $\mathbf{0 . 2 8}$ & $\mathbf{0 . 4 7}$ \\
\hline
\end{tabular}


Table 4: Correlogram: Log-change in credit measures

This table presents correlations between the log-difference of different credit measures. The first row of each credit measure reports the correlation coefficient. ${ }^{*}$ denotes statistical significance at the $5 \%$-level. The second row shows p-values, while the third row reports the number of observations.

\begin{tabular}{lllll}
\hline & $\begin{array}{l}\text { Total credit to } \\
\text { firms }\end{array}$ & $\begin{array}{l}\text { Domestic bank } \\
\text { credit to private } \\
\text { sector }\end{array}$ & $\begin{array}{l}\text { Total internati- } \\
\text { onal claims }\end{array}$ & $\begin{array}{l}\text { International } \\
\text { claims to non- } \\
\text { banks }\end{array}$ \\
\hline Domestic bank credit & $\mathbf{0 . 2 5 *}$ & $\mathbf{1}$ & \\
& $\begin{array}{l}\text { (0.03) } \\
77\end{array}$ & 77 & & \\
Total international claims & $\mathbf{0 . 0 8}$ & $\mathbf{0 . 3 1 *}$ & $\mathbf{1}$ & \\
& $(0.47)$ & $(0.01)$ & 77 & \\
Int. claims to non-banks & 77 & 77 & $\mathbf{0 . 4 1 *}$ & $\mathbf{1}$ \\
& $\mathbf{0 . 0 6}$ & $\mathbf{0 . 1 0}$ & $(0.00)$ & 77 \\
Int. claims to banks & $(0.63)$ & $(0.37)$ & 77 & $\mathbf{0 . 0 2}$ \\
& 77 & 77 & $\mathbf{0 . 8 0}$ & $(0.00)$ \\
& $\mathbf{0 . 0 1}$ & $\mathbf{0 . 2 4}$ & 77 & 77 \\
\hline
\end{tabular}


Table 5: Summary statistics

This table gives summary statistics for the baseline regression sample.

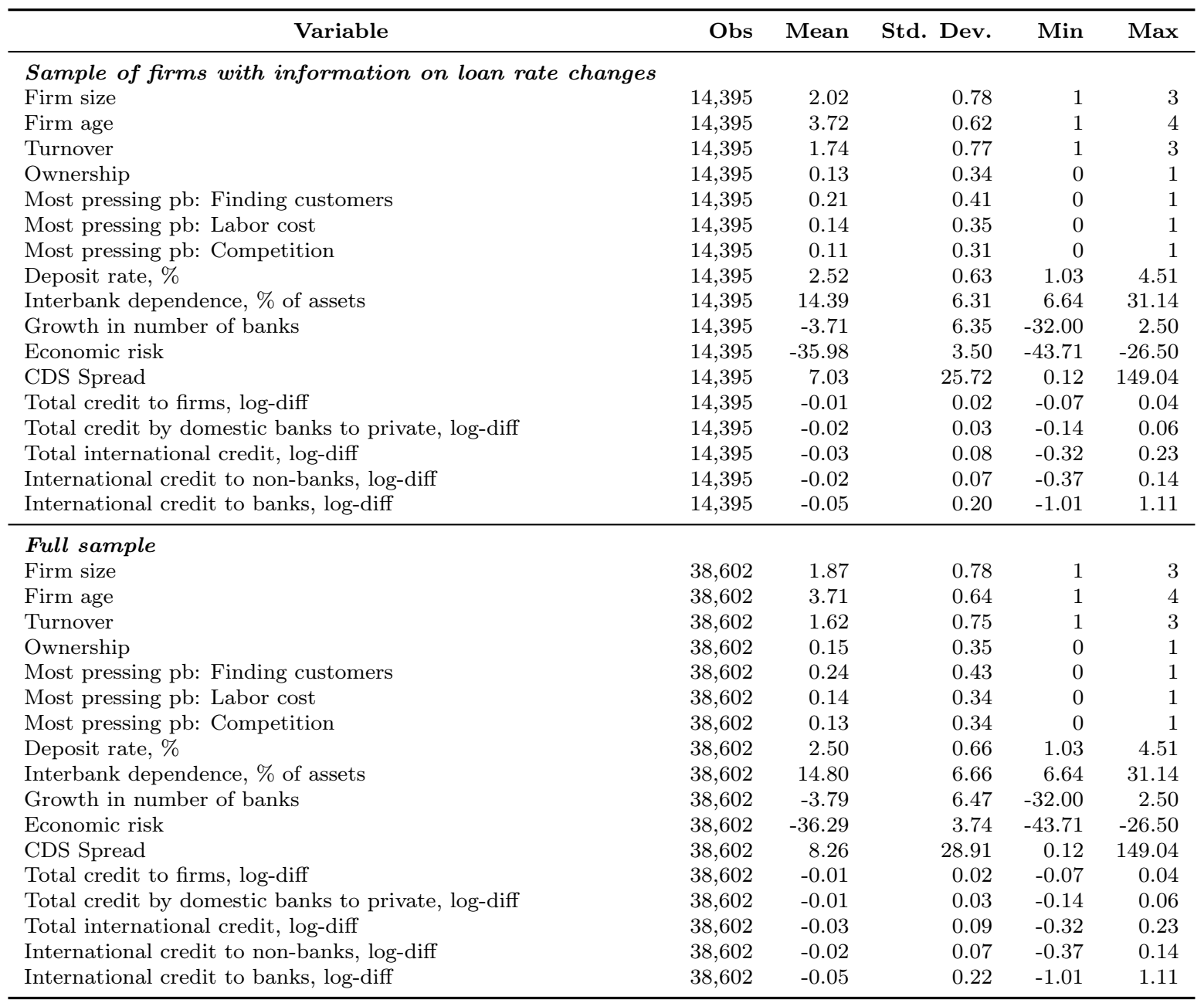


Table 6: Determinants of loan application

This table reports estimation results (average marginal effects) from the first-stage estimation of a probit with selection. The dependent variable equals 1 if a firm has applied for a loan. Credit aggregates are expressed as log-differences. A set of country, sector, and time dummies is included in each regression. Robust standard errors are clustered at the firm-level. ${ }^{*},{ }^{* *}$, and ${ }^{* * *}$ denote statistical significance at the $10-, 5-$, and 1\%-level.

\begin{tabular}{|c|c|c|c|}
\hline & $(1)$ & $(2)$ & $(3)$ \\
\hline Firm size & $\begin{array}{c}0.074^{* * *} \\
(0.005)\end{array}$ & $\begin{array}{c}0.074^{* * *} \\
(0.005)\end{array}$ & $\begin{array}{c}0.074^{* * *} \\
(0.005)\end{array}$ \\
\hline Firm age & $\begin{array}{l}-0.005 \\
(0.004)\end{array}$ & $\begin{array}{l}-0.005 \\
(0.004)\end{array}$ & $\begin{array}{l}-0.005 \\
(0.004)\end{array}$ \\
\hline Turnover & $\begin{array}{c}0.018^{* * *} \\
(0.005)\end{array}$ & $\begin{array}{c}0.018^{* * *} \\
(0.005)\end{array}$ & $\begin{array}{c}0.018^{* * *} \\
(0.005)\end{array}$ \\
\hline Ownership & $\begin{array}{c}-0.080^{* * *} \\
(0.008)\end{array}$ & $\begin{array}{c}-0.079^{* * *} \\
(0.008)\end{array}$ & $\begin{array}{c}-0.079^{* * *} * \\
(0.008)\end{array}$ \\
\hline Most pressing pb: Finding customers & $\begin{array}{c}-0.099 * * * \\
(0.006)\end{array}$ & $\begin{array}{c}-0.098 * * * \\
(0.006)\end{array}$ & $\begin{array}{c}-0.099 * * * \\
(0.006)\end{array}$ \\
\hline Most pressing pb: Competition & $\begin{array}{l}-0.115^{* * *} \\
(0.008)\end{array}$ & $\begin{array}{l}-0.115^{* * *} \\
(0.008)\end{array}$ & $\begin{array}{c}-0.115^{* * *} \\
(0.008)\end{array}$ \\
\hline Most pressing pb: Labor cost & $\begin{array}{c}-0.064^{* * *} \\
(0.007)\end{array}$ & $\begin{array}{c}-0.064^{* * *} \\
(0.007)\end{array}$ & $\begin{array}{c}-0.064^{* * *} \\
(0.007)\end{array}$ \\
\hline Deposit rate, $\%$ & $\begin{array}{l}-0.014 \\
(0.011)\end{array}$ & $\begin{array}{l}-0.015 \\
(0.011)\end{array}$ & $\begin{array}{l}-0.014 \\
(0.011)\end{array}$ \\
\hline Interbank dependence, $\%$ of assets & $\begin{array}{c}0.005^{* *} \\
(0.002)\end{array}$ & $\begin{array}{c}0.007^{* * *} \\
(0.002)\end{array}$ & $\begin{array}{c}0.007^{* * *} \\
(0.002)\end{array}$ \\
\hline Growth in number of banks & $\begin{array}{c}-0.001^{*} \\
(0.001)\end{array}$ & $\begin{array}{c}-0.001 \\
(0.001)\end{array}$ & $\begin{array}{l}-0.001 \\
(0.001)\end{array}$ \\
\hline Economic risk & $\begin{array}{c}0.008^{* * *} \\
(0.003)\end{array}$ & $\begin{array}{c}0.008^{* * *} \\
(0.003)\end{array}$ & $\begin{array}{c}0.009 * * * \\
(0.003)\end{array}$ \\
\hline CDS Spread & $\begin{array}{c}-0.000^{* *} \\
(0.000)\end{array}$ & $\begin{array}{c}-0.000^{*} \\
(0.000)\end{array}$ & $\begin{array}{c}-0.000^{* *} \\
(0.000)\end{array}$ \\
\hline Total credit to firms, log-diff & $\begin{array}{c}0.453^{* * *} \\
(0.173)\end{array}$ & & \\
\hline Total credit by domestic banks to private, log-diff & & $\begin{array}{c}0.14 \\
(0.142)\end{array}$ & $\begin{array}{c}0.093 \\
(0.144)\end{array}$ \\
\hline Total international credit, log-diff & & $\begin{array}{c}-0.01 \\
(0.040)\end{array}$ & \\
\hline International credit to non-banks, log-diff & & & $\begin{array}{c}-0.073 \\
(0.047)\end{array}$ \\
\hline International credit to banks, log-diff & & & $\begin{array}{c}0.008 \\
(0.014)\end{array}$ \\
\hline Country dummies & yes & yes & yes \\
\hline Sector dummies & yes & yes & yes \\
\hline Wave dummies & yes & yes & yes \\
\hline Observations & 38602 & 38602 & 38602 \\
\hline No. of firms & 26032 & 26032 & 26032 \\
\hline Pseudo R-squared & 0.065 & 0.064 & 0.064 \\
\hline
\end{tabular}




\section{Table 7: Determinants of loan rate increases}

This table reports estimation results (average marginal effects) from pooled probit regressions, with and without a Heckman selection approach. The dependent variable equals 1 if a firm reports an increase in its loan rate. Credit aggregates are expressed as log-differences. A set of country, sector and time dummies is included in each regression. Robust standard errors are clustered at the firm-level. ${ }^{*},{ }^{* *}$, and *** denote statistical significance at the 10-, 5-, and 1\%-level.

\begin{tabular}{|c|c|c|c|c|c|c|}
\hline & $\begin{array}{c}(1) \\
\text { Probit }\end{array}$ & $\begin{array}{c}(2) \\
\text { Heckman }\end{array}$ & $\begin{array}{c}(3) \\
\text { Probit }\end{array}$ & $\begin{array}{c}(4) \\
\text { Heckman }\end{array}$ & $\begin{array}{c}(5) \\
\text { Probit }\end{array}$ & $\begin{array}{c}(6) \\
\text { Heckman }\end{array}$ \\
\hline Firm size & $\begin{array}{c}0.005 \\
(0.007)\end{array}$ & $\begin{array}{c}-0.015^{*} \\
(0.008)\end{array}$ & $\begin{array}{c}0.004 \\
(0.007)\end{array}$ & $\begin{array}{c}-0.016^{* *} \\
(0.008)\end{array}$ & $\begin{array}{c}0.004 \\
(0.007)\end{array}$ & $\begin{array}{c}-0.016^{* *} \\
(0.008)\end{array}$ \\
\hline Firm age & $\begin{array}{l}0.011^{*} \\
(0.006)\end{array}$ & $\begin{array}{l}0.012^{*} \\
(0.006)\end{array}$ & $\begin{array}{l}0.011^{*} \\
(0.006)\end{array}$ & $\begin{array}{c}0.012^{*} \\
(0.006)\end{array}$ & $\begin{array}{l}0.011^{*} \\
(0.006)\end{array}$ & $\begin{array}{c}0.012^{*} \\
(0.006)\end{array}$ \\
\hline Turnover & $\begin{array}{c}0.007 \\
(0.007)\end{array}$ & $\begin{array}{c}0.002 \\
(0.007)\end{array}$ & $\begin{array}{c}0.008 \\
(0.007)\end{array}$ & $\begin{array}{c}0.003 \\
(0.007)\end{array}$ & $\begin{array}{c}0.008 \\
(0.007)\end{array}$ & $\begin{array}{c}0.003 \\
(0.007)\end{array}$ \\
\hline Ownership & $\begin{array}{c}-0.035 * * * \\
(0.011)\end{array}$ & $\begin{array}{l}-0.011 \\
(0.012)\end{array}$ & $\begin{array}{c}-0.035^{* * *} \\
(0.011)\end{array}$ & $\begin{array}{l}-0.011 \\
(0.012)\end{array}$ & $\begin{array}{c}-0.035^{* * *} \\
(0.011)\end{array}$ & $\begin{array}{l}-0.011 \\
(0.012)\end{array}$ \\
\hline Most pressing pb: Finding customers & $\begin{array}{c}-0.030 * * * \\
(0.009)\end{array}$ & $\begin{array}{l}-0.009 \\
(0.010)\end{array}$ & $\begin{array}{c}-0.032 * * * \\
(0.009)\end{array}$ & $\begin{array}{c}-0.01 \\
(0.010)\end{array}$ & $\begin{array}{c}-0.032^{* * *} \\
(0.009)\end{array}$ & $\begin{array}{c}-0.01 \\
(0.010)\end{array}$ \\
\hline Deposit rate, $\%$ & $\begin{array}{c}0.042^{* *} \\
(0.017)\end{array}$ & $\begin{array}{c}0.044^{* * *} \\
(0.016)\end{array}$ & $\begin{array}{c}0.072^{* * *} \\
(0.018)\end{array}$ & $\begin{array}{c}0.071^{* * *} \\
(0.017)\end{array}$ & $\begin{array}{c}0.062^{* * *} * \\
(0.017)\end{array}$ & $\begin{array}{c}0.061^{* * *} \\
(0.016)\end{array}$ \\
\hline Interbank dependence, $\%$ of assets & $\begin{array}{c}0.016^{* * *} \\
(0.004)\end{array}$ & $\begin{array}{c}0.013^{* * *} * \\
(0.004)\end{array}$ & $\begin{array}{c}0.009 * * \\
(0.004)\end{array}$ & $\begin{array}{c}0.006^{*} \\
(0.003)\end{array}$ & $\begin{array}{c}0.009 * * \\
(0.004)\end{array}$ & $\begin{array}{c}0.006^{*} \\
(0.004)\end{array}$ \\
\hline Growth in number of banks & $\begin{array}{c}-0.003^{* * *} \\
(0.001)\end{array}$ & $\begin{array}{c}-0.003^{* *} \\
(0.001)\end{array}$ & $\begin{array}{c}-0.006 * * * \\
(0.001)\end{array}$ & $\begin{array}{c}-0.005^{* * *} \\
(0.001)\end{array}$ & $\begin{array}{c}-0.006^{* * *} \\
(0.001)\end{array}$ & $\begin{array}{c}-0.005 * * * \\
(0.001)\end{array}$ \\
\hline Economic risk & $\begin{array}{c}0.021^{* * *} \\
(0.005)\end{array}$ & $\begin{array}{c}0.017^{* * *} \\
(0.004)\end{array}$ & $\begin{array}{c}0.015^{* * *} \\
(0.005)\end{array}$ & $\begin{array}{c}0.011^{* *} \\
(0.005)\end{array}$ & $\begin{array}{c}0.018^{* * *} \\
(0.005)\end{array}$ & $\begin{array}{c}0.014^{* * *} \\
(0.005)\end{array}$ \\
\hline CDS Spread & $\begin{array}{c}0.000 \\
(0.000)\end{array}$ & $\begin{array}{c}0.000 \\
(0.000)\end{array}$ & $\begin{array}{l}-0.001 \\
(0.000)\end{array}$ & $\begin{array}{c}0 \\
(0.000)\end{array}$ & $\begin{array}{c}0.000 \\
(0.000)\end{array}$ & $\begin{array}{c}0.000 \\
(0.000)\end{array}$ \\
\hline Total credit to firms, log-diff & $\begin{array}{c}-1.536 * * * \\
(0.272)\end{array}$ & $\begin{array}{c}-1.536 * * * \\
(0.261)\end{array}$ & & & & \\
\hline Total credit by domestic banks to private, log-diff & & & $\begin{array}{c}-0.196 \\
(0.241)\end{array}$ & $\begin{array}{c}-0.221 \\
(0.227)\end{array}$ & $\begin{array}{c}-0.096 \\
(0.244)\end{array}$ & $\begin{array}{l}-0.117 \\
(0.230)\end{array}$ \\
\hline Total international credit, log-diff & & & $\begin{array}{c}-0.281^{* * *} \\
(0.067)\end{array}$ & $\begin{array}{c}-0.255^{* * *} \\
(0.063)\end{array}$ & & \\
\hline International credit to non-banks, log-diff & & & & & $\begin{array}{l}-0.125 \\
(0.077)\end{array}$ & $\begin{array}{c}-0.095 \\
(0.073)\end{array}$ \\
\hline International credit to banks, log-diff & & & & & $\begin{array}{c}-0.068^{* * *} \\
(0.023)\end{array}$ & $\begin{array}{c}-0.065^{* * *} \\
(0.022)\end{array}$ \\
\hline Country dummies & yes & yes & yes & yes & yes & yes \\
\hline Sector dummies & yes & yes & yes & yes & yes & yes \\
\hline Wave dummies & yes & yes & yes & yes & yes & yes \\
\hline Observations & 14395 & 14395 & 14395 & 14395 & 14395 & 14395 \\
\hline No. of firms & 10825 & 10825 & 10825 & 10825 & 10825 & 10825 \\
\hline Pseudo R-squared & 0.169 & 0.092 & 0.168 & 0.092 & 0.168 & 0.091 \\
\hline
\end{tabular}


Table 8: Determinants of loan rate increases, interactions with firm size

This table reports estimation results (average marginal effects) from pooled probit regressions, with and without a Heckman selection approach. The dependent variable equals 1 if a firm reports an increase in its loan rate. Credit aggregates are expressed as log-differences. A set of country, sector, and time dummies is included in each regression. Robust standard errors are clustered at the firm-level. ${ }^{*},{ }^{* *}$, and *** denote statistical significance at the 10-, 5-, and 1\%-level.

\begin{tabular}{|c|c|c|c|c|c|c|}
\hline & $\begin{array}{c}(1) \\
\text { Probit }\end{array}$ & $\begin{array}{c}(2) \\
\text { Heckman }\end{array}$ & $\begin{array}{c}(3) \\
\text { Probit }\end{array}$ & $\begin{array}{c}(4) \\
\text { Heckman }\end{array}$ & $\begin{array}{c}(5) \\
\text { Probit }\end{array}$ & $\begin{array}{c}(6) \\
\text { Heckman }\end{array}$ \\
\hline Firm age & $\begin{array}{l}0.012^{*} \\
(0.006)\end{array}$ & $\begin{array}{l}0.011^{*} \\
(0.006)\end{array}$ & $\begin{array}{l}0.012^{*} \\
(0.006)\end{array}$ & $\begin{array}{l}0.011^{*} \\
(0.006)\end{array}$ & $\begin{array}{l}0.011^{*} \\
(0.006)\end{array}$ & $\begin{array}{l}0.011^{*} \\
(0.006)\end{array}$ \\
\hline Turnover & $\begin{array}{c}0.01 \\
(0.007)\end{array}$ & $\begin{array}{l}-0.004 \\
(0.007)\end{array}$ & $\begin{array}{l}0.012^{*} \\
(0.007)\end{array}$ & $\begin{array}{l}-0.003 \\
(0.007)\end{array}$ & $\begin{array}{l}0.012^{*} \\
(0.007)\end{array}$ & $\begin{array}{l}-0.003 \\
(0.007)\end{array}$ \\
\hline Ownership & $\begin{array}{c}-0.034^{* * *} \\
(0.011)\end{array}$ & $\begin{array}{l}-0.009 \\
(0.012)\end{array}$ & $\begin{array}{c}-0.034^{* * *} * \\
(0.011)\end{array}$ & $\begin{array}{c}-0.01 \\
(0.012)\end{array}$ & $\begin{array}{c}-0.034^{* * *} * \\
(0.011)\end{array}$ & $\begin{array}{c}-0.01 \\
(0.012)\end{array}$ \\
\hline Most pressing pb: Finding customers & $\begin{array}{c}-0.030^{* * * *} \\
(0.009)\end{array}$ & $\begin{array}{l}-0.006 \\
(0.010)\end{array}$ & $\begin{array}{c}-0.031 * * * \\
(0.009)\end{array}$ & $\begin{array}{l}-0.007 \\
(0.010)\end{array}$ & $\begin{array}{c}-0.031 * * * \\
(0.009)\end{array}$ & $\begin{array}{l}-0.007 \\
(0.010)\end{array}$ \\
\hline Larger firms & $\begin{array}{l}-0.011 \\
(0.012)\end{array}$ & $\begin{array}{c}-0.024 * * \\
(0.011)\end{array}$ & $\begin{array}{l}-0.018 \\
(0.013)\end{array}$ & $\begin{array}{c}-0.030 * * \\
(0.012)\end{array}$ & $\begin{array}{l}-0.014 \\
(0.012)\end{array}$ & $\begin{array}{c}-0.027 * * \\
(0.012)\end{array}$ \\
\hline Deposit rate, \% & $\begin{array}{c}0.041^{* *} \\
(0.017)\end{array}$ & $\begin{array}{c}0.042^{* * *} * \\
(0.016)\end{array}$ & $\begin{array}{c}0.072^{* * *} * \\
(0.018)\end{array}$ & $\begin{array}{c}0.071 * * * \\
(0.017)\end{array}$ & $\begin{array}{c}0.061 * * * \\
(0.017)\end{array}$ & $\begin{array}{c}0.060^{* * *} * \\
(0.016)\end{array}$ \\
\hline Interbank dependence, $\%$ of assets & $\begin{array}{c}0.016^{* * *} * \\
(0.004)\end{array}$ & $\begin{array}{c}0.013^{* * *} * \\
(0.004)\end{array}$ & $\begin{array}{c}0.009^{* *} \\
(0.004)\end{array}$ & $\begin{array}{l}0.006^{*} \\
(0.003)\end{array}$ & $\begin{array}{c}0.009^{* *} \\
(0.004)\end{array}$ & $\begin{array}{l}0.006^{*} \\
(0.003)\end{array}$ \\
\hline Growth in number of banks & $\begin{array}{c}-0.003^{* * *} \\
(0.001)\end{array}$ & $\begin{array}{c}-0.003 * * \\
(0.001)\end{array}$ & $\begin{array}{c}-0.006^{* * * *} \\
(0.001)\end{array}$ & $\begin{array}{c}-0.005^{* * * *} \\
(0.001)\end{array}$ & $\begin{array}{c}-0.006^{* * * *} \\
(0.001)\end{array}$ & $\begin{array}{c}-0.005^{* * * *} \\
(0.001)\end{array}$ \\
\hline Economic risk & $\begin{array}{c}0.021^{* * *} \\
(0.005)\end{array}$ & $\begin{array}{c}0.016^{* * *} \\
(0.004)\end{array}$ & $\begin{array}{c}0.015^{* * *} * \\
(0.005)\end{array}$ & $\begin{array}{c}0.011^{* *} \\
(0.005)\end{array}$ & $\begin{array}{c}0.018^{* * *} \\
(0.005)\end{array}$ & $\begin{array}{c}0.014^{* * *} \\
(0.005)\end{array}$ \\
\hline CDS Spread & $\begin{array}{c}0.000 \\
(0.000)\end{array}$ & $\begin{array}{c}0.000 \\
(0.000)\end{array}$ & $\begin{array}{l}-0.001 \\
(0.000)\end{array}$ & $\begin{array}{c}0.000 \\
(0.000)\end{array}$ & $\begin{array}{c}0.000 \\
(0.000)\end{array}$ & $\begin{array}{c}0.000 \\
(0.000)\end{array}$ \\
\hline Total credit to firms, log-diff & $\begin{array}{c}-1.229^{* * *} \\
(0.294)\end{array}$ & $\begin{array}{c}-1.254^{* * *} \\
(0.276)\end{array}$ & & & & \\
\hline Total credit to firms $\mathrm{x}$ Larger firms & $\begin{array}{c}-1.095^{* * *} \\
(0.395)\end{array}$ & $\begin{array}{c}-0.946^{* *} \\
(0.371)\end{array}$ & & & & \\
\hline Total credit by domestic banks to private, log-diff & & & $\begin{array}{l}-0.094 \\
(0.253)\end{array}$ & $\begin{array}{l}-0.164 \\
(0.234)\end{array}$ & $\begin{array}{c}0.011 \\
(0.256)\end{array}$ & $\begin{array}{l}-0.058 \\
(0.237)\end{array}$ \\
\hline Total credit by domestic banks $\mathrm{x}$ Larger firms & & & $\begin{array}{l}-0.481 \\
(0.319)\end{array}$ & $\begin{array}{l}-0.319 \\
(0.301)\end{array}$ & $\begin{array}{l}-0.451 \\
(0.322)\end{array}$ & $\begin{array}{c}-0.28 \\
(0.304)\end{array}$ \\
\hline Total international credit, log-diff & & & $\begin{array}{c}-0.209^{* * *} * \\
(0.072)\end{array}$ & $\begin{array}{c}-0.182^{* * *} * \\
(0.067)\end{array}$ & & \\
\hline Total international credit $\mathrm{x}$ Larger firms & & & $\begin{array}{c}-0.265 * * * \\
(0.101)\end{array}$ & $\begin{array}{c}-0.257^{* * *} * \\
(0.094)\end{array}$ & & \\
\hline International credit to non-banks, log-diff & & & & & $\begin{array}{c}-0.093 \\
(0.086)\end{array}$ & $\begin{array}{c}-0.062 \\
(0.080)\end{array}$ \\
\hline International credit to non-banks $\mathrm{x}$ Larger firms & & & & & $\begin{array}{l}-0.086 \\
(0.114)\end{array}$ & $\begin{array}{l}-0.079 \\
(0.106)\end{array}$ \\
\hline International credit to banks, log-diff & & & & & $\begin{array}{c}-0.043^{*} \\
(0.025)\end{array}$ & $\begin{array}{l}-0.037 \\
(0.023)\end{array}$ \\
\hline International credit to banks $\mathrm{x}$ Larger firms & & & & & $\begin{array}{c}-0.096 * * \\
(0.042)\end{array}$ & $\begin{array}{c}-0.105^{* * *} * \\
(0.039)\end{array}$ \\
\hline Country dummies & yes & yes & yes & yes & yes & yes \\
\hline Sector dummies & yes & yes & yes & yes & yes & yes \\
\hline Wave dummies & yes & yes & yes & yes & yes & yes \\
\hline Observations & 14395 & 38602 & 14395 & 38602 & 14395 & 38602 \\
\hline No. of firms & 10825 & 10825 & 10825 & 10825 & 10825 & 10825 \\
\hline Pseudo R-squared & 0.169 & 0.089 & 0.169 & 0.089 & 0.168 & 0.089 \\
\hline
\end{tabular}


Table 9: Determinants of loan rate increases, including large firms

This table reports estimation results (average marginal effects) from pooled probit regressions, including large firms (i.e. firms with more than 250 employees), with and without a Heckman selection approach. The dependent variable equals 1 if a firm reports an increase in its loan rate. Credit aggregates are expressed as log-differences. A set of country, sector, and time dummies is included in each regression. Robust standard errors are clustered at the firm-level. ${ }^{* * *}$, and ${ }^{* * *}$ denote statistical significance at the 10-, 5-, and 1\%-level.

\begin{tabular}{|c|c|c|c|c|c|c|}
\hline & $\begin{array}{c}(1) \\
\text { Probit }\end{array}$ & $\begin{array}{c}(2) \\
\text { Heckman }\end{array}$ & $\begin{array}{c}(3) \\
\text { Probit }\end{array}$ & $\begin{array}{c}(4) \\
\text { Heckman }\end{array}$ & $\begin{array}{c}(5) \\
\text { Probit }\end{array}$ & $\begin{array}{c}(6) \\
\text { Heckman }\end{array}$ \\
\hline Firm size & $\begin{array}{c}0.003 \\
(0.007)\end{array}$ & $\begin{array}{c}-0.017^{* *} \\
(0.008)\end{array}$ & $\begin{array}{c}0.003 \\
(0.007)\end{array}$ & $\begin{array}{c}-0.018^{* *} \\
(0.008)\end{array}$ & $\begin{array}{c}0.003 \\
(0.007)\end{array}$ & $\begin{array}{c}-0.018^{* *} \\
(0.008)\end{array}$ \\
\hline Firm age & $\begin{array}{l}0.012^{*} \\
(0.006)\end{array}$ & $\begin{array}{c}0.013^{* *} \\
(0.006)\end{array}$ & $\begin{array}{l}0.012^{*} \\
(0.006)\end{array}$ & $\begin{array}{c}0.012 * * \\
(0.006)\end{array}$ & $\begin{array}{l}0.012^{*} \\
(0.006)\end{array}$ & $\begin{array}{c}0.012^{* *} \\
(0.006)\end{array}$ \\
\hline Turnover & $\begin{array}{c}0.009 \\
(0.006)\end{array}$ & $\begin{array}{c}0.006 \\
(0.006)\end{array}$ & $\begin{array}{c}0.009 \\
(0.006)\end{array}$ & $\begin{array}{c}0.007 \\
(0.006)\end{array}$ & $\begin{array}{c}0.009 \\
(0.006)\end{array}$ & $\begin{array}{c}0.007 \\
(0.006)\end{array}$ \\
\hline Ownership & $\begin{array}{c}-0.038^{* * *} \\
(0.011)\end{array}$ & $\begin{array}{l}-0.013 \\
(0.012)\end{array}$ & $\begin{array}{c}-0.038^{* * *} \\
(0.011)\end{array}$ & $\begin{array}{l}-0.013 \\
(0.012)\end{array}$ & $\begin{array}{c}-0.038^{* * *} \\
(0.011)\end{array}$ & $\begin{array}{l}-0.014 \\
(0.012)\end{array}$ \\
\hline Most pressing pb: Finding customers & $\begin{array}{c}-0.031^{* * *} \\
(0.009)\end{array}$ & $\begin{array}{l}-0.011 \\
(0.010)\end{array}$ & $\begin{array}{c}-0.033^{* * *} \\
(0.009)\end{array}$ & $\begin{array}{l}-0.012 \\
(0.010)\end{array}$ & $\begin{array}{c}-0.032^{* * *} \\
(0.009)\end{array}$ & $\begin{array}{l}-0.011 \\
(0.010)\end{array}$ \\
\hline Deposit rate, $\%$ & $\begin{array}{c}0.037 * * \\
(0.017)\end{array}$ & $\begin{array}{c}0.039 * * \\
(0.016)\end{array}$ & $\begin{array}{c}0.070 * * * \\
(0.017)\end{array}$ & $\begin{array}{c}0.069^{* * *} * \\
(0.016)\end{array}$ & $\begin{array}{c}0.058 * * * \\
(0.017)\end{array}$ & $\begin{array}{c}0.058^{* * * *} \\
(0.016)\end{array}$ \\
\hline Interbank dependence, $\%$ of assets & $\begin{array}{c}0.016^{* * *} \\
(0.004)\end{array}$ & $\begin{array}{c}0.013^{* * *} \\
(0.004)\end{array}$ & $\begin{array}{c}0.009 * * \\
(0.004)\end{array}$ & $\begin{array}{l}0.006^{*} \\
(0.003)\end{array}$ & $\begin{array}{c}0.009^{* *} \\
(0.004)\end{array}$ & $\begin{array}{l}0.006^{*} \\
(0.003)\end{array}$ \\
\hline Growth in number of banks & $\begin{array}{c}-0.004^{* * *} \\
(0.001)\end{array}$ & $\begin{array}{c}-0.003^{* * *} \\
(0.001)\end{array}$ & $\begin{array}{c}-0.006^{* * *} \\
(0.001)\end{array}$ & $\begin{array}{c}-0.005^{* * *} \\
(0.001)\end{array}$ & $\begin{array}{c}-0.006^{* * *} \\
(0.001)\end{array}$ & $\begin{array}{c}-0.005^{* * *} \\
(0.001)\end{array}$ \\
\hline Economic risk & $\begin{array}{c}0.021^{* * *} \\
(0.004)\end{array}$ & $\begin{array}{c}0.017^{* * *} \\
(0.004)\end{array}$ & $\begin{array}{c}0.015^{* * *} \\
(0.005)\end{array}$ & $\begin{array}{c}0.012^{* *} \\
(0.005)\end{array}$ & $\begin{array}{c}0.018^{* * *} \\
(0.005)\end{array}$ & $\begin{array}{c}0.015^{* * *} \\
(0.005)\end{array}$ \\
\hline CDS Spread & $\begin{array}{c}0.000 \\
(0.000)\end{array}$ & $\begin{array}{c}0.000 \\
(0.000)\end{array}$ & $\begin{array}{l}-0.001 \\
(0.000)\end{array}$ & $\begin{array}{c}0.000 \\
(0.000)\end{array}$ & $\begin{array}{c}0.000 \\
(0.000)\end{array}$ & $\begin{array}{c}0.000 \\
(0.000)\end{array}$ \\
\hline Total credit to firms, log-diff & $\begin{array}{c}-1.606^{* * *} \\
(0.269)\end{array}$ & $\begin{array}{c}-1.611^{* * *} \\
(0.260)\end{array}$ & & & & \\
\hline Total credit by domestic banks to private, log-diff & & & $\begin{array}{l}-0.175 \\
(0.238)\end{array}$ & $\begin{array}{l}-0.196 \\
(0.225)\end{array}$ & $\begin{array}{l}-0.062 \\
(0.242)\end{array}$ & $\begin{array}{l}-0.077 \\
(0.229)\end{array}$ \\
\hline Total international credit, log-diff & & & $\begin{array}{c}-0.297^{* * *} \\
(0.066)\end{array}$ & $\begin{array}{c}-0.272^{* * *} \\
(0.063)\end{array}$ & & \\
\hline International credit to non-banks, log-diff & & & & & $\begin{array}{c}-0.122 \\
(0.076)\end{array}$ & $\begin{array}{l}-0.091 \\
(0.073)\end{array}$ \\
\hline International credit to banks, log-diff & & & & & $\begin{array}{c}-0.071 * * * \\
(0.023)\end{array}$ & $\begin{array}{c}-0.068^{* * *} * \\
(0.022)\end{array}$ \\
\hline Country dummies & yes & yes & yes & yes & yes & yes \\
\hline Sector dummies & yes & yes & yes & yes & yes & yes \\
\hline Wave dummies & yes & yes & yes & yes & yes & yes \\
\hline Observations & 14878 & 14878 & 14878 & 14878 & 14878 & 14878 \\
\hline No. of firms & 11197 & 11197 & 11197 & 11197 & 11197 & 11197 \\
\hline Pseudo R-squared & 0.167 & 0.063 & 0.167 & 0.062 & 0.166 & 0.062 \\
\hline
\end{tabular}




\section{Table 10: Determinants of loan rate increases, sector level}

This table reports estimation results from fractional probit regressions. The dependent variable is the share of firms in sector $s$, country $c$ at time $t$ that report an increase in loan rates. Credit aggregates are expressed as log-differences. A set of country, sector, time and sector-time dummies is included in each regression. Estimations are conducted using robust standard errors. ${ }^{*},{ }^{* *}$, and ${ }^{* * *}$ denote statistical significance at the 10-, 5-, and 1\%-level.

\begin{tabular}{|c|c|c|c|}
\hline & (1) & $(2)$ & $(3)$ \\
\hline Deposit rate, $\%$ & $\begin{array}{c}0.069 \\
(0.078)\end{array}$ & $\begin{array}{c}0.12 \\
(0.082)\end{array}$ & $\begin{array}{c}0.093 \\
(0.082)\end{array}$ \\
\hline Interbank dependence, $\%$ of assets & $\begin{array}{c}0.035^{* *} \\
(0.018)\end{array}$ & $\begin{array}{c}0.021 \\
(0.017)\end{array}$ & $\begin{array}{c}0.021 \\
(0.017)\end{array}$ \\
\hline Growth in number of banks & $\begin{array}{l}-0.007 \\
(0.005)\end{array}$ & $\begin{array}{c}-0.016^{* * *} \\
(0.005)\end{array}$ & $\begin{array}{c}-0.014^{* *} \\
(0.006)\end{array}$ \\
\hline Economic risk & $\begin{array}{c}0.088^{* * *} \\
(0.019)\end{array}$ & $\begin{array}{c}0.062^{* * *} \\
(0.024)\end{array}$ & $\begin{array}{c}0.074 * * * \\
(0.024)\end{array}$ \\
\hline CDS Spread & $\begin{array}{c}0.000 \\
(0.002)\end{array}$ & $\begin{array}{c}0.000 \\
(0.002)\end{array}$ & $\begin{array}{c}0.000 \\
(0.002)\end{array}$ \\
\hline Total credit to firms, log-diff & $\begin{array}{c}-4.339 * * * \\
(1.179)\end{array}$ & & \\
\hline Total credit by domestic banks to private, log-diff & & $\begin{array}{l}-1.014 \\
(1.029)\end{array}$ & $\begin{array}{c}-0.667 \\
(1.088)\end{array}$ \\
\hline Total international credit, log-diff & & $\begin{array}{c}-0.920^{* * *} \\
(0.244)\end{array}$ & \\
\hline International credit to non-banks, log-diff & & & $\begin{array}{l}-0.123 \\
(0.368)\end{array}$ \\
\hline International credit to banks, log-diff & & & $\begin{array}{c}-0.202^{* *} \\
(0.086)\end{array}$ \\
\hline Country dummies & yes & yes & yes \\
\hline Sector dummies & yes & yes & yes \\
\hline Wave dummies & yes & yes & yes \\
\hline Sector-wave dummies & yes & yes & yes \\
\hline Observations & 308 & 308 & 308 \\
\hline No. of countries & 11 & 11 & 11 \\
\hline Pseudo R-squared & 0.133 & 0.133 & 0.132 \\
\hline
\end{tabular}




\section{Data Appendix}

\begin{tabular}{|c|c|c|}
\hline Variable & Source & Description \\
\hline \multicolumn{3}{|l|}{ Costs of financing } \\
\hline Increase in lending rates & $\begin{array}{l}\text { SAFE } \\
\text { Q10, a): Have lending rates for your } \\
\text { firms increased, decreased or remained } \\
\text { the same over the past } 6 \text { months? }\end{array}$ & $\begin{array}{l}\text { 1: increased } \\
\text { missing: DK/NA }\end{array}$ \\
\hline & & 0: otherwise \\
\hline \multicolumn{3}{|l|}{ Firm characteristics } \\
\hline Firm size & $\begin{array}{l}\text { SAFE } \\
\text { D1: How many people does your com- } \\
\text { pany employ(part- or full time)? }\end{array}$ & $\begin{array}{l}\text { Categorical variable } \\
\text { 1: } 1-9 \text { employees } \\
\text { 2: } 10-49 \text { employees } \\
\text { 3: } 50 \text { - } 249 \text { employees } \\
\text { 4: } 250 \text { employees or more }\end{array}$ \\
\hline
\end{tabular}

\begin{tabular}{ll} 
& SAFE \\
& D5: In which year was your firm registe- \\
red? & \\
\hline & \\
& SAFE age \\
& D3: What is the main activity of your \\
Sector &
\end{tabular}

\section{Categorical variable}

1: less than 2 years

2: 2 years or more, less than 5 years

3: 5 years or more, less than 10 years

4: 10 years or more

\section{Categorical variable}

1: Construction

2: Industry (Mining, Manufacturing)

3: Services (Transport, Real Estate, Other Services)

4: Trade (Wholesale and Retail)

Missing: D3>7

$\begin{array}{ll} & \text { SAFE } \\ & \underline{\mathrm{D} 4} \text { : What was annual turnover of your } \\ \text { Turnover } & \text { company last year? }\end{array}$

\section{Categorical variable}

1: up to 2 mio $€$

Turnover

2: over 2 and up to 10 mio $€$

3: over 10 and up to 50 mio $€$

4: over 50 mio $€$

Missing: DK/NA

\begin{tabular}{|c|c|}
\hline & SAFE \\
\hline Firm ownership & D6: Who are the owners of your firm? \\
\hline
\end{tabular}

1: Shareholders, other firms, other

0: family or entrepreneurs, venture capi-

tal firms, natural person, one owner only missing: DK/NA

SAFE 1: Finding customers

Waves until 2012W1

Most pressing problem: finding customers

0: all other categories (Access to finance, competition, costs of production or labor, availability of skilled stuff or experienced managers, regulation, other)

Q0: What is currently your most presmissing: DK/NA and missings from QO $\overline{\sin } \mathrm{g}$ problem?

Waves as of 2012W2

Construct Q0 from Q0b and Q0c

SAFE

Waves until 2012W1

Most pressing problem: input costs

Q0: What is currently your most pressing problem?

Waves as of 2012W2

Construct Q0 from Q0b and Q0c
1: Costs of production or labour 0: all other categories (Finding customers, competition, access to finance, availability of skilled stuff or experienced managers, regulation, other) missing: DK/NA and missings from Q0 


\section{SAFE}

Waves until 2012W1

Most pressing problem: competition

Q0: What is currently your most pressing problem?

Waves as of 2012W2

Construct Q0 from Q0b and Q0c

Total credit
Total credit to private
non-financial firms

BIS, Statistics on credit to the private non-financial sector

Waves as of 2012W2
Construct Q0 from Q0b and Q0c

non-financial firms
1: Competition
0: all other categories (Finding custo-
mers, access to finance, availability of
skilled stuff or experienced managers, re-
gulation, costs of production or labor, ot-
her)
missing: DK/NA and missings from Q0

Credit to non-financial corporations from all sources independent of the country of origin or type of lender. This includes e.g. securitised credits held by the non-bank financial sector or crossborder lending. The coverage of financial instruments includes loans and debt securities. Adjusted for breaks, billions of local currency (EUR), original frequency: quarterly

Cross-border credit

Total international BIS, Consolidated Banking Statistics

Claims (amounts outstanding at quarcross-border bank claims ter end) on destination country by all reporting countries, immediate borrower basis, in mio. USD, international claims (cross-border + local in foreign currency), original frequency: quarterly

\begin{tabular}{lrc}
\hline International & cross- & BIS, Consolidated Banking Statistics \\
border bank & claims on & \\
non-bank & private & \\
sector &
\end{tabular}
Claims on destination country by all reporting countries, immediate borrower basis, in mio. USD, international claims (cross-border + local in foreign currency), non-bank private sector includes claims against all non-banks (i.e. including financial non-banks and households), original frequency: quarterly

\begin{tabular}{|c|c|c|}
\hline $\begin{array}{l}\text { International cross- } \\
\text { border bank claims on } \\
\text { banking sector }\end{array}$ & BIS, Consolidated Banking Statistics & $\begin{array}{l}\text { Claims on destination country banks by } \\
\text { all reporting countries, immediate borro- } \\
\text { wer basis, in mio. USD, foreign claims } \\
\text { (cross-border + local in foreign cur- } \\
\text { rency), original frequency: quarterly }\end{array}$ \\
\hline \multicolumn{3}{|l|}{ Domestic credit } \\
\hline $\begin{array}{l}\text { Domestic bank credit to } \\
\text { private non-financial } \\
\text { sector (non-financial } \\
\text { corporations, house- } \\
\text { holds, NPISHs) }\end{array}$ & $\begin{array}{l}\text { BIS, Statistics on credit to the private } \\
\text { non-financial sector }\end{array}$ & $\begin{array}{l}\text { Credit extended by domestic deposit- } \\
\text { taking corporations except the central } \\
\text { bank such as commercial banks, sa- } \\
\text { vings banks or credit unions and money- } \\
\text { market funds, adjusted for breaks, billi- } \\
\text { ons of local currency (EUR), original fre- } \\
\text { quency: quarterly. }\end{array}$ \\
\hline \multicolumn{3}{|l|}{ Other macro variables } \\
\hline $\begin{array}{l}\text { Euro-Dollar nominal ex- } \\
\text { change rate }\end{array}$ & IMF, IFS & $\begin{array}{l}\text { Euro per USD, end of period, original fre- } \\
\text { quency: quarterly }\end{array}$ \\
\hline Consumer price index & IMF, IFS & $\begin{array}{l}\text { All items, index } 2010=100 \text {, original fre- } \\
\text { quency: quarterly }\end{array}$ \\
\hline Gross domestic product & Eurostat & $\begin{array}{l}\text { In current mio EUR, according to ESTV } \\
\text { 2010, original frequency: quarterly }\end{array}$ \\
\hline
\end{tabular}


Deposit interest rate

ECB, MFI Interest Rate Statistics

ECB, Statistics on Consolidated Banking Data

ECB, Statistics on Consolidated Banking Data

Economic risk

International Country Risk Guide (ICRG), PRS Group
Interest rate on deposits with agreed maturity, annualized agreed rate, counterpart sector: non-financial corporations and households, original frequency: monthly

Interbank market dependence in $\%$ of total assets, domestic banks and foreign controlled subsidiaries and branches, original frequency: half-yearly

\begin{tabular}{ll}
\hline Number of banks & $\begin{array}{l}\text { ECB, Statistics on Consolidated Banking } \\
\text { Data }\end{array}$ \\
\hline Economic risk & $\begin{array}{l}\text { International Country Risk Guide } \\
(\text { ICRG }), \text { PRS Group }\end{array}$
\end{tabular}

Total number of credit institutions, domestic banks and foreign controlled subsidiaries and branches, original frequency: half-yearly

Economic risk rating, based on different risk components (GDP per capita, GDP growth, inflation, fiscal budget balance, current account balance), original frequency: yearly

CDS spreads

Thomson Reiters Datastream ads, original frequency: daily 